\title{
Quarterly Report on the Ferrocyanide Safety Program for the Period Ending December 31, 1994
}

Prepared for the U.S. Department of Energy Office of Environmental Restoration and

Waste Management

\section{(2) Westinghouse \\ Hanford Company Richland, Washington}

Hanford Operations and Engineering Contractor for the

U.S. Depertment of Energy under Contract DE-AC06-87RL10930 


\section{LEGAL DISCLAIMER}

This report wes prepared as an account of work sponsored by an egency of the United States Government. Neither the United States Government nor any agency thereof, nor any of their employees, nor any of their contractors, subcontractors or their employees, makes any warranty, express or implied, or assumes any legal liability or responsibility for the accuracy, completeness, or any third party's use or the results of such use of any information, apparatus, product, or process disclosed, or represents that its use would not infringe privately owned rights. Reference herein to any specific commercial product, process, or service by trade name, trademark, manufacturer, or otherwise, does not necessarily constitute or imply its endorsement, recommendation, or favoring by the United States Government or any agency thereof or its contractors or subcontractors. The views and opinions of authors expressed herein do not necessarily state or reflect those of the United States Government or any agency thereof.

This report has been reproduced from the best available copy. Available in paper copy and microfiche.

Available to the U.S. Department of Energy and its contractors from

Office of Scientific and Technical Information

P.O. Box 62

Oak Ridge, TN 37831

(615) $576-8401$

Available to the public from the U.S. Department of Commerce National Technical Information Service

5285 Port Royal Road

Springfield, VA 22161

(703) $487-4650$

Printed in the Unitod States of Ameriea

DISCLM-1.CHP (1-91) 


\section{DISCLAIMER}

Portions of this document may be illegible in electronic image products. Images are produced from the best available original document. 


\title{
Quarterly Report on the Ferrocyanide Safety Progam for the Period Ending December 31, 1994
}

\author{
J. E. Meacham \\ R. J. Cash \\ G. T. Dukelow \\ Date Published \\ January 1995
}

Prepared for the U.S. Department of Energy Office of Environmental Restoration and Waste Management

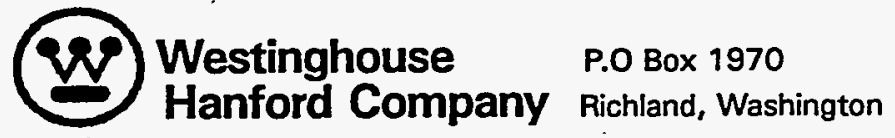

Hanford Operations and Engineering Contractor for the U.S. Department of Energy under Contract DE-AC06-87RL10930

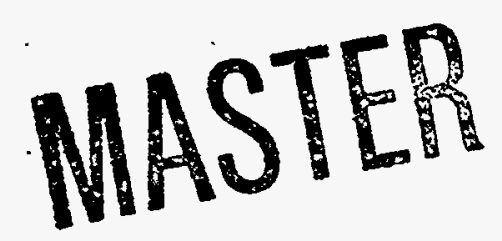

Approved for Public Release 


\section{RELEASE AUTHORIZATION}

Document Number: WHC-EP-0474-15

Document Title: Quarterly Report on the Ferrocyanide Safety Program for the Period Ending December 31, 1994

Release Date: $\quad$ February 1, 1995

This document was reviewed following the procedures described in WHC-CM-3-4 and is:

APPROVED FOR PUBLIC RELEASE

W.HC Information Release Administration Specialist:

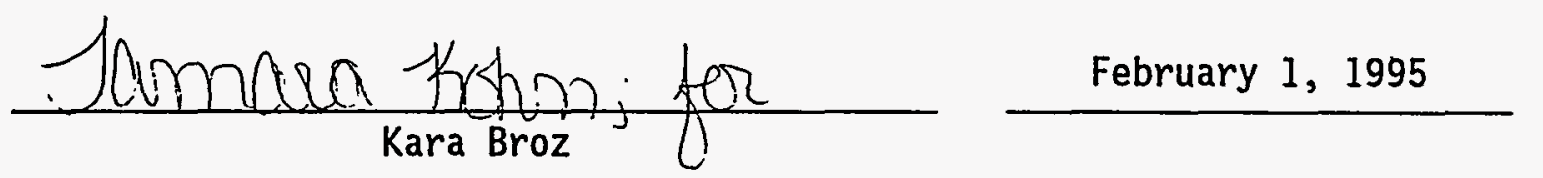




\title{
QUARTERLY REPORT ON THE FERROCYANIDE SAFETY PROGRAM FOR THE PERIOD ENDING DECEMBER 31, 1994
}

\author{
J. E. Meacham \\ R. J. Cash \\ G. T. Dukelow
}

\begin{abstract}
This is the fifteenth quarterly report on the progress of activities addressing the Ferrocyanide Safety Issue associated with Hanford Site high-level radioactive waste tanks. Progress in the Ferrocyanide Safety Program is reviewed, including work addressing the six parts of Defense Nuclear Facilities Safety Board Recommendation 90-7 (FR 1990). All work activities are described in the revised program plan (DOE 1994b), and this report follows the same format presented there. A summary of the key events occurring this quarter is presented in Section 1.2. More detailed discussions of progress are located in Sections 2.0 through 4.0.
\end{abstract}




\section{CONTENTS}

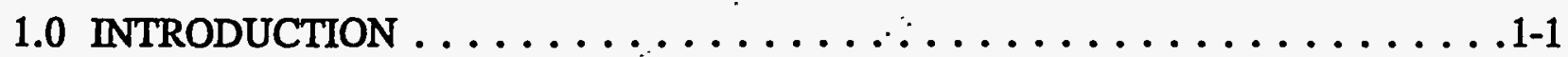

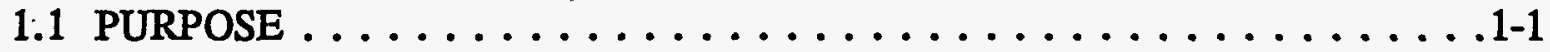

1.2 QUARTERLY HIGHLIGHTS $\ldots \ldots \ldots \ldots \ldots \ldots \ldots \ldots \ldots \ldots$

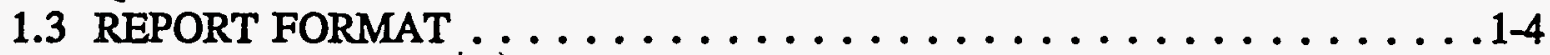

1.4 BACKGROUND . . . . . . . . . . . . . . . . .

2.0 FERROCYANIDE SAFETY DOCUMENTATION $\ldots \ldots \ldots \ldots \ldots \ldots \ldots$ 2-1

3.0 ACTIONS TO COMPLETE DNFSB RECOMMENDATION $90-7 \ldots \ldots$. . . . . . 3-1

3.1 ENHANCED TEMPERATURE MEASUREMENT $\ldots \ldots \ldots \ldots \ldots \ldots 3-1$

3.1.1 Instrument Trees . . . . . . . . . . . . . . . . . . 3-1

3.1.2 Upgrades to Existing Temperature Monitoring Instrumentation . . . . 3-2

3.1.3 Hot Spot Thermal Modeling . . . . . . . . . . . . . 3-3

3.1.4 Infrared Scanning System . . . . . . . . . . . . . . . . 3-4

3.2 CONTINUOUS TEMPERATURE MONITORING $\ldots \ldots \ldots \ldots \ldots \ldots$ 3-4

3.3 COVER GAS MODELING $\ldots \ldots \ldots \ldots \ldots \ldots \ldots \ldots \ldots$

3.3.1 Interim Flammable Gas Monitoring . . . . . . . . . . . 3-5

3.3.2 Continuous Gas Monitoring $\ldots \ldots \ldots \ldots \ldots \ldots \ldots$. . . . . .

3.4 FERROCYANIDE WASTE CHARACTERIZATION $\ldots \ldots \ldots \ldots \ldots$. . . .

3.4.1 Core Sampling and Analyses . . . . . . . . . . . 3-8

3.4.2 Estimation of Moisture Content . . . . . . . . . . . . 3-15

3.4.3 Moisture Retention Properties of Ferrocyanide Simulants . . . . . 3-20

3.5 CHEMICAL REACTION STUDIES . . . . . . . . . . . . . 3-26

3.5.1 Chemical Reaction Studies at Pacific Northwest Laboratory . . . . 3-26

3.5.2 Preparation and Characterization of Ferrocyanide Simulants . . . . 3-30

3.6 EMERGENCY RESPONSE PLANNING $\ldots \ldots \ldots \ldots \ldots \ldots \ldots \ldots$ 3-32

4.0 IMPLEMENTATION OF THE WYDEN AMENDMENT . . . . . . . . . 4-1

4.1 THE WATCH LIST $\ldots \ldots \ldots \ldots \ldots \ldots \ldots \ldots \ldots \ldots \ldots . . \ldots .1$

4.2 TEMPERATURE MONITORING $\ldots \ldots \ldots \ldots \ldots \ldots \ldots \ldots . \ldots \ldots$

4.3 PRESSURE MONITORING . . . . . . . . . . . . . . 4-3

5.0 PROGRAM SCHEDULES AND MILESTONES $\ldots \ldots \ldots \ldots \ldots \ldots \ldots$. . . . . .

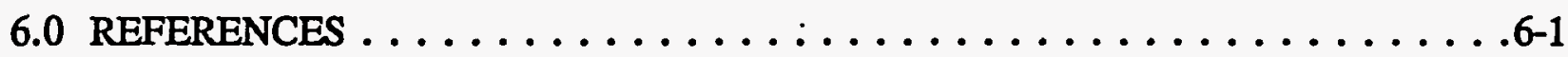

APPENDIX

FERROCYANIDE TANK INFORMATION SUMMARY $\ldots \ldots \ldots \ldots \ldots$ A-1 


\section{LIST OF FIGURES}

3-1 FTIR Spectra of Hanford Site Mixed Waste from Three Tanks. . . . . . . . . . 3-12

3-2 Relative Humidity (RH) Isotherms for Sludge Simulants After Exposure to

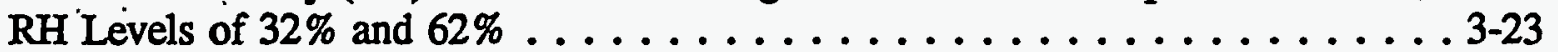

3-3 Relative Available Moisture Content for Drying Experiment of King (1994) . . . 3-24

3-4 Relative Available Moisture for U-Plant Simulant Exposed to Four Levels of Constant Relative Humidity . . . . . . . . . . . . . . . . 3-24

3-5 Production of Ammonia During Hydrolysis of In-Farm-1B in a Gamma Field as a Function of Temperature $\ldots \ldots \ldots \ldots \ldots \ldots \ldots \ldots \ldots \ldots \ldots \ldots .28$

3-6 Production of Ammonia During the Hydrolysis of In-Farm-1B in a Gamma Field at $80^{\circ} \mathrm{C}$ in the Presence or Absence of Oxygen . . . . . . . . . . . 3-29

5-1 Ferrocyanide Waste Tank Safety Schedule $\ldots \ldots \ldots \ldots \ldots \ldots . . \ldots$ 5-2

\section{LIST OF TABLES}

A-1 Summary of Contents and Status of Ferrocyanide Taniks $\ldots \ldots \ldots \ldots$ A-3

A-2 Ferrocyanide Tank Vapor Sampling Summary $\ldots \ldots \ldots \ldots \ldots \ldots$ A-5 


\section{- LIST OF TERMS}

BSE

CASS

CCSEM

CTI

CPAC

DNFSB

DOE

DQO

EA

EDTA/en

EDX

EIS

FAI

FR

FTIR

FY

g-mole

GAO

IC

IR

ISB

$\mathrm{kW}$

LANL

LOW

NIR

PNL

$\mathrm{Rad} / \mathrm{h}$

$\mathrm{RH}$

RSST

SA

SAR

SEM

SST

TC

TMACS

USQ

vol\%

VSP

WSU

wt\%
Backscattered Electron Detection

Computer Automated Surveillance System

Computer Controlled Scanning Electron Microscopy

Contact-Temperature Criterion

Center for Process Analytical Chemistry

Defense Nuclear Facilities Safety Board

U.S. Department of Energy

Data Quality Objectives

Environmental Assessment

Ethylenediaminetetraacetic Acid/Ethylenediamine

Energy Dispersive X-Ray Spectroscopy

Environmental Impact Statement

Fauske and Associates, Inc.

Federal Register

Fourier Transform Infrared

Fiscal Year

Gram-Mole

U.S. General Accounting Office

Ion Chromatography

Infrared

Interim Safety Basis

Kilowatt

Los Alamos National Laboratory

Liquid Observation Well

Near Infrared

Pacific Northwest Laboratory

Rad Per Hour

Relative Humidity

Reactive Systems Screening Tool (small adiabatic calorimeter at FAI)

Safety Assessment

Safety Analysis Report

Scanning Electron Microscopy

Single-Shell Tank

Thermocouple

Tank Monitor and Control System

Unreviewed Safety Question

Volume Percent

Vent Sizing Package (large adiabatic calorimeter at FAI)

Washington State University

Weight Percent 


\subsection{INTRODUCTION}

\subsection{PURPOSE}

This quarterly report provides a status of the activities underway on the Ferrocyanide Safety Issue at the Hanford Site including actions in response to Defense Nuclear Facilities Safety Board (DNFSB) Recommendation 90-7 (FR 1990). In March 1991, a DNFSB implementation plan (Cash 1991) responding to the six parts of Recommendation 90-7 was prepared and sent to the DNFSB. A Ferrocyanide Safety Program Plan addressing the total Ferrocyanide Safety Program, including the six parts of DNFSB Recommendation 90-7, was released in September 1994 (DOE 1994b). Activities in the program plan are underway or have been completed, and the status of each is described in Sections 2.0 though 3.0 of this report.

\subsection{QUARTERLY HIGHLIGHTS}

- One of the seven instrument trees scheduled to be installed in ferrocyanide tanks was inserted in tank 241-T-107 this quarter using the new ultrahigh-pressure borehead. Only 15 liters ( 4 gal.) of water were required to insert the tree through $1.8 \mathrm{~m}(6 \mathrm{ft})$ of waste. Installation of the six remaining instrument trees will be completed in fiscal year (FY) 1995 after the respective tanks have been core sampled.

- All of the new instrument trees will be connected to the Tank Monitor and Control System (TMACS) for continuous temperature monitoring by the end of FY 1995. Three newly-installed instrument trees remain to be connected. The TMACS installation design has been completed for all seven trees remaining to be installed. Twenty-three trees in 18 ferrocyanide tanks are now being continuously monitored by TMACS.

- Vapor samples were taken from seven ferrocyanide tanks this quarter using the heated sampling tubes and mobile vapor sampling laboratory. Surprisingly high ammonia concentrations ( $\sim 1000$ parts per million) were noted in two of the tanks (241-BY-107 and -BY-108). Supplied breathing air is required for areas in the BY Tank Farm as a result of these high concentrations. Table A-2 in Appendix A contains a summary of vapor sampling results through this quarter for the 18 ferrocyanide tanks.

- Modeling studies and tank vapor sampling results show that continuous gas monitoring of the ferrocyanide tank head space is not required. The revised Ferrocyanide Program Plan concludes that no further work is required in this area. The U.S. Department of Energy (DOE) approved the Program Plan and transmitted the document to the DNFSB in December 1994. 
- Approval was received from DOE in November 1994 to remove two tanks, 241-BX-102 and -106, from the Ferrocyanide Watch List based on safety documentation provided earlier. Four other tanks (241-BX-110, -BX-111, -BY-101, and $-\mathrm{T}-101$ ) were previously removed in July 1993 . Eighteen ferrocyanide tanks remain on the Watch List.

- Auger samples were obtained from two different risers in tank 241-C-108. Recoveries were very good (approaching 100\%) except for the top auger sample (two were taken) from the first riser. Analyses are now in progress with the 45-day screening report due in January 1995.

- Auger samples were also obtained from two different risers in tank 241-BY-108. Recoveries were quite poor, yielding only 15 and $30 \%$. This amount of sample may be sufficient since the purpose of this sampling was to determine if any organic material might be present in the saltcake. This tank showed higher than expected organic content during vapor sampling in FY 1994 (see Table A-2, Appendix A). Analyses are now in progress with the 45-day screening report due in February 1995.

- Thirteen segments were attempted by the rotary-mode core sampling truck in tank 241-BY-106 this quarter. Segment recoveries varied from 0 to 95 volume percent (vol\%), with most at the low end. Surprisingly; all recovered segments appeared to be saltcake. Historical records indicate that at least the last two or three segments should contain sludge that originated from the U-Plant ferrocyanide scavenging flowsheet. A second attempt will be made in the same riser to obtain better recoveries.

- Fourier transform infrared (FTIR) spectroscopy is being investigated as a sensitive technique for determining the quantitative moisture content of ferrocyanide and organic waste. The technique is also adaptable for in situ measurement of waste surface moisture in the tanks. Results indicate that the spectra are dominated by strong absorption of water molecules. Various organic species should also be detectable using FTIR spectroscopy.

- A small task on Mossbauer spectroscopy is investigating the physical and chemical nature of iron within ferrocyanide tank waste. The National Aeronautics and Space Administration (NASA) recently developed a miniaturized Mossbauer spectrometer that is small enough to perform elevation scans in the LOWs. Mossbauer spectroscopy can distinguish between ferrocyanide and ferricyanide complexes and almost any iron compound that might exist within tank waste.

- Computer analysis is in progress on the neutron probe (near- and far-field) scans completed in ferrocyanide tanks with liquid observation wells (LOWs). Based on analyses to date, two field unit probes (thermal and epithermal) are now being fabricated for new scans in the LOWs. The ultrahigh-pressure borehead is being adapted for installation of new LOWs that will be inserted in the waste tanks during the next several years. 
- Deployment of the electromagnetic induction (EMI) technique for determining tank waste moisture levels was turned over to Westinghouse Hanford Company for further investigations at the beginning of FY 1995. This technique has a large range of interrogation in the waste than the neutron probe. EMI modeling was started at Washington State University which will define the theoretical capabilities this technique. A completed vendor survey indicates that there are several companies with good expertise in this field.

- Modeling of waste drainage and consolidation is continuing with new emphasis being placed on moisture retention in saltcake waste. Waste simulants will be exposed to varying relative humidity $(\mathrm{RH})$ atmospheres to determine drying and wetting properties as a function of RH. Recent test results are presented in detail in Section 3.4.3.

- Additional aging experiments were conducted this quarter to determine the effect of temperature on the hydrolysis reaction. Additional hydrolysis experiments were conducted under irradiation at temperatures of $80^{\circ} \mathrm{C}$ and $100^{\circ} \mathrm{C}$ and $1 \times 10^{5} \mathrm{Rad} / \mathrm{h}$. Only ammonia production results were available by the quarter's end. Ammonia production observed at $80^{\circ} \mathrm{C}$ was intermediate between the 70 and $90^{\circ} \mathrm{C}$ results obtained previously. There was also an induction period of about 12 days before significant ammonia was measured. The $100^{\circ} \mathrm{C}$ test is still continuing (see Section 3.4.1).

- Although some radioactive work has restarted in the Pacific Northwest Laboratory 325 Building in December 1994, approval to resume the cyanide speciation and cesium uptake experiments is still on hold. Each task and.respective laboratory operation are being approved individually.

- Pure sodium nickel ferrocyanide is being prepared and tested at Fauske and Associates, Inc. (FAI) to determine its chemical reaction properties with stoichiometric mixtures of sodium nitrate/nitrite as a function of water content. FAI has developed a ContactTemperature Ignition (CTI) criterion that will define the upper compositional limits for placing condensed-phase Watch List tanks in the Safe category.

- The rationale for not installing pressure monitors in ferrocyanide tanks was prepared and submitted to DOE last quarter. The rationale was also included in the revised Ferrocyanide Program Plan which concludes that pressure monitoring is not warranted and recommends that no further work be done in this area. The Ferrocyanide Program Plan was approved by DOE and transmitted to the DNFSB in December 1994. 


\subsection{REPORT FORMAT}

Progress of activities under each of the six parts of DNFSB Recommendation 90-7 are arranged in the same order as the program plan (DOE 1994b). The arrangement also follows the same order provided in Recommendation 90-7. To report on progress, each part of the recommendation is repeated in italics, followed by paragraphs explaining the scope of work on each part or subpart of the recommendation. Subheadings for each task activity report the following:

- Progress During Reporting Period

- Planned Work for Subsequent Months

- Problem Areas and Action Taken

- Milestone Status.

\subsection{BACKGROUND}

Various high-level radioactive wastes from defense operations have accumulated at the Hanford Site in underground storage tanks since the mid-1940s. During the 1950s, additional tank storage space was required to support the defense mission. To obtain this additional storage volume within a short time period, and to minimize the need for constructing additional storage tanks, Hanford Site scientists developed a process to scavenge ${ }^{137} \mathrm{Cs}$ and ${ }^{90} \mathrm{Sr}$ from tank waste liquids. In implementing this process, approximately 140 metric tons (154 tons) of ferrocyanide were added to waste that was later routed to a number of Hanford Site single-shell tanks (SSTs) (Sloat 1954, 1955).

In the presence of oxidizing material such as sodium nitrate and/or nitrite, ferrocyanide can be made to react exothermically by heating it to high temperatures or by applying an electrical spark of sufficient energy (Cady 1993). However, fuel, oxidizers, and temperature are all important parameters. If fuel, oxidizers, or high temperatures (initiators) are not present in sufficient amounts, then a runaway or propagating reaction cannot occur.

In 1990, little was known about the potential hazards of a ferrocyanide-nitrate/nitrite reaction in Hanford Site SSTs. Because the safety envelope was not adequately defined by existing analyses, an inadequacy existed in the authorization basis ${ }^{1}$. That is, the existing safety analysis report (Smith 1986) and subsequent analyses such as the 1987 Environmental Impact Statement (EIS) (DOE 1987) did not adequately define the conditions necessary to preclude

${ }^{1}$ The DOE authorization basis characterizes the facility design basis and operational requirements for each nuclear facility. The authorization basis is described in documents such as facility safety analysis reports and other safety analyses, hazard classification documents, technical safety requirements, DOE issued safety evaluation reports, and facility-specific commitments, such as safety assessments for specific tank operations and the Interim Safety Basis (Wagoner 1993). 
propagating reactions in the ferrocyanide waste; therefore, an Unreviewed Safety Question (USQ) was declared (Deaton 1990).

Based on the knowledge gained from simulant studies, theoretical analyses, and analyses of actual waste samples, safety criteria were defined for the ferrocyanide waste (Postma et al. 1994a). These criteria were reviewed and accepted by outside reviewers and reviewers within DOE. The USQ was closed on March 1, 1994 by the DOE Assistant Secretary for Environmental Restoration and Waste Management (Sheridan 1994a).

In September 1990, an Ad Hoc Task Force report (Kress et al. 1990) recommended that studies be performed to provide information on (1) the potential for a ferrocyanidenitrate/nitrite explosion; (2) the conditions necessary in the tanks to initiate an explosion; and (3) the potential consequences of such an occurrence. The U.S General Accounting. Office (GAO) advised the Secretary of Energy to implement these recommendations (Peach 1990). A close-out report addressing all three of the GAO recommendations was submitted to DOE in June 1994 (Payne 1994a). The report summarizes the progress made on determining the potential for ferrocyanide reactions in Hanford Site ferrocyanide tanks, and the conditions necessary to sustain an exothermic ferrocyanide reaction.

In March 1989 (Nguyen 1989), using process knowledge, process records, transfer records, and $\log$ books, 22 Hanford Site tanks were identified as potentially containing 1,000 g-moles $^{1}$ [211 kg (465 lb)] or more of ferrocyanide [as the $\mathrm{Fe}(\mathrm{CN})_{6}^{4}$ anion]. Two additional ferrocyanide tanks were identified in January 1991 (Borsheim and Cash 1991), increasing the number of ferrocyanide tanks to 24. To avert possible injury to personnel and damage to the facility or environment, strict controls were identified for these and other safety issue tanks in the Operating Specifications for Watch List Tanks (WHC 1990). Tanks identified via this document [see WHC. (1994) for the latest revision] have been commonly referred to as Watch List tanks. In October 1990 (Deaton 1990), the Ferrocyanide Safety Issue was declared a USQ (see Section 2.1) because the safety envelope for these tanks was no longer considered to be bounded by the existing safety analysis report (Smith 1986).

In November 1990, the Wyden Amendment (Public Law 101-510, Section 3137, 1990) was enacted. This law required the identification of Hanford Site tanks that may have a serious potential for release of high-level waste (see Section 4.0). In February 1991 (Harmon 1991), the 24 ferrocyanide tanks were among the tanks identified, and were included in the subsequent July 1991 report to Congress (Watkins 1991) that responded to the Wyden Amendment. However, re-examination of the historical records (Borsheim and Simpson 1991) indicated that six of the 24 tanks did not contain the requisite 1,000 g-moles of ferrocyanide. Therefore, these six tanks should not have been included on the Watch List nor been identified in the response to the Wyden Amendment. The six tanks were subsequently removed from the Watch List (Anttonen 1993, Sheridan 1994b).

${ }^{1}$ The $1,000 \mathrm{~g}$-moles criterion has since been replaced with a $115 \mathrm{cal} / \mathrm{g}$ fuel concentration criterion. See Section 4.1 for discussion. 
WHC-EP-0474-15

This page intentionally left blank. 


\subsection{FERROCYANIDE SAFETY DOCUMENTATION}

The USQ process depends on an authorization basis that describes those aspects of the facility design basis and operational requirements relied on by DOE to authorize operation. The authorization basis is described in documents such as facility Safety Analysis Reports (SARs) and other safety analyses, hazard classification documents, technical safety requirements, DOE-issued safety evaluation reports, and facility-specific commitments, such as Safety Assessments (SAs) and the Interim Safety Basis (ISB). The potential hazards of a ferrocyanide-nitrate/nitrite reaction were discovered to represent an inadequacy in the then-existing authorization basis. The Ferrocyanide USQ was closed on March 1, 1994 by the DOE Assistant Secretary for Environmental Restoration and Waste Management (Sheridan 1994a). Progress on the remaining safety documentation for resolving the Ferrocyanide Safety Issue is reviewed in this section.

Safety and Environmental Assessments. SAs are documents prepared to provide the technical basis to assess the safety of a proposed activity and to provide proper controls to maintain safety. The SA and the accompanying Environmental Assessment (EA) for that operation provide the basis for DOE authorization of the proposed activities. SAs have been approved for dome space sampling of all ferrocyanide tanks, waste surface sampling, push-mode and rotary-mode core sampling, thermocouple (TC)/instrument tree installation in sound and assumed leaker tanks, and removal of pumpable liquid (interim stabilization). A generic EA covering all proposed operations in the tank farms was approved and a Finding of No Significant Impact issued by DOE (Gerton 1994). Approval of the generic EA provides adequate National Environmental Policy Act coverage for the planned Ferrocyanide Safety Program activities.

The authorization basis for intrusive tank operations was combined into one document, the ISB, which was approved in November 1993 (Wagoner 1993). Safety documentation concerning the ferrocyanide hazard was updated to reflect the approved ferrocyanide safety criteria and closure of the Ferrocyanide USQ.

Hazard Assessment. A report assessing the ferrocyanide waste tank hazards was issued in July 1992 (Grigsby et al. 1992). The report reviewed the understanding of the ferrocyanide hazard at that time, and presented an integrated evaluation and interpretation of historical data and then-available information. Much more data are now available on the potential for exothermic ferrocyanide reactions in Hanford Site SSTS. A final ferrocyanide hazard assessment will be submitted to DOE (tentatively planned for September 1995) as a technical basis to remove the remaining ferrocyanide tanks from the Watch List. Technical information from all Ferrocyanide Safety Program tasks will be compiled into this document.

Ferrocyanide Program Plan. A ferrocyanide program plan was submitted to the DNFSB this quarter (O'Leary 1994). The program plan outlines activities planned to address DNFSB Recommendation 90-7, to meet the Wyden Amendment requirements (Public Law 101-510, Section 3137, 1990), and to remove the remaining ferrocyanide tanks from the Watch List. 
All ferrocyanide program activities are scheduled to be completed by the end of FY 1997. However, an increased understanding of radiolytic and chemical degradation (aging) of ferrocyanide indicates that little ferrocyanide remains, and the assumption that core sampling of all the tanks is required may not be valid. Core sampling and analyses of only those tanks that bound aging (i.e., tanks with conditions least conducive to aging) could result in resolution of the Ferrocyanide Safety Issue much earlier and at a substantially reduced cost. As more core sample data become available, the need to sample all the ferrocyanide tanks will be reexamined. 


\subsection{ACTIONS TO COMPLETE DNFSB RECOMMENDATION 90-7}

This section follows the format of the program plan (DOE 1994b) and describes all work associated with the Ferrocyanide Safety Program. Where applicable, each task activity is described relative to the DNFSB Recommendation (90-7.1 through 90-7.6). The specific part of the recommendation is given, followed by a summary of activities underway to respond to that part of Recommendation 90-7 (if not already closed out).

\subsection{ENHANCED TEMPERATURE MEASUREMENT}

"Immediate steps should be taken to add instrumentation as necessary to the SSTs containing ferrocyanide that will establish whether hot spots exist or may develop in the future in the stored waste. The instrumentation should include, as a minimum, additional thermocouple trees. Trees should be introduced at several radial locations in all tanks containing substantial amounts of ferrocyanide, to measure the temperature as a function of elevation at these radii. The use of infrared techniques to survey the surface of waste in tanks should continue to be investigated as a priority matter, and on the assumption that this method will be found valuable, monitors based on it should be installed now in the ferrocyanide bearing tanks."

\subsubsection{Instrument Trees}

Work in several areas has developed a broader knowledge base and has warranted several changes in the approach to implementing this recommendation. Originally, it was planned to add several temperature measurement instruments to each tank. This plan has been modified to ensure that at least one instrument tree with replaceable temperature-sensing elements is in each ferrocyanide tank. Additionally, at least two operational temperature-sensing elements should be in the waste to ensure a true temperature measurement, and one or more in the dome space.

The new data that have warranted this action include the following: (1) many of the TC elements in the existing trees have been returned to service, and measured temperatures are as expected; (2) thermal modeling to date (McLaren 1994a, 1994b) and an enhanced understanding of waste properties that shows formation of hot spots in ferrocyanide tanks is not credible (Dickinson et al. 1993, Epstein et al. 1994); and (3) new calculations of tank heat content based on tank temperatures show lower values than previous estimates (Crowe et al. 1993, McLaren 1994a, 1994b).

When completed, there will be two instrument trees in all but three ferrocyanide tanks (241-BY-106, -111 and -112). Tanks 241-BY-105 and -106 already contain instrument trees with replaceable temperature sensing elements. Earlier, tanks 241-BY-111 and -112 had no operable instrument tree, and the waste temperatures were measured via a dedicated TC 
element installed in each tank's LOW. New instrument trees with replaceable temperature-sensing elements were installed in these two tanks in March 1993. The existing instrument trees in the tanks will be monitored in addition to newly installed trees. The older trees are expected eventually to fail in a manner such that they cannot be repaired, and they will undoubtedly not be replaced.

- Progress During Reporting Period. Seven new instrument trees, each with a heated vapor sampling tube, have been fabricated for insertion into assumed leaker ferrocyanide tanks. One of the seven trees was installed in tank 241-T-107 on November 11, 1994, using the ultrahigh-pressure borehead. Only 15 liters (4 gal.) of water were required to insert the tree through $1.8 \mathrm{~m}(6 \mathrm{ft})$ of waste. All equipment and safety documentation supporting insertion of the remaining trees has been completed. Installation of instrument trees in the remaining assumed leaker tanks will continue after the respective tanks have been core sampled, or it is determined that an adequate number of risers are available.

- Planned Work for Subsequent Months. Six instrument trees will be installed into the remaining assumed leaker ferrocyanide tanks, most after characterization of the affected tank is complete. One instrument tree will be installed before April 30, 1995 and the other five trees will be installed by September 1995.

- Problem Areas and Action Taken. None.

- Milestone Status.

- April 30, 1995. Westinghouse Hanford Company completes installation of two of seven instrument trees in assumed leaker ferrocyanide tanks (Tri-Party Agreement Milestone M-40-02B). One tree was installed in November 1994 in tank 241-T-107.

- September 30, 1995. Westinghouse Hanford Company completes installation of remaining five instrument trees in assumed leaker ferrocyanide tanks (Tri-Party Agreement Milestone $\mathrm{M}-40-02$ ).

\subsubsection{Upgrades to Existing Temperature Monitoring Instrumentation}

This task determined the operability and accuracy of previously installed TC elements in the original 24 Ferrocyanide Watch List tanks. The original and newly installed instrument trees provide temperature measurements for the ferrocyanide tanks.

Field measurements were taken in 1991 on each TC element in the then-existing trees to determine the resistance and voltage across the junction and across each lead to ground. The exact condition of each TC element was determined by resistance and voltage measurements (Bussell 1992). This work was completed in FY 1991 with a total of 265 TC elements being 
evaluated. Work in FY 1992 focused on repair and recovery of 92 TC elements that were found to be failed or marginal in performance. This task was completed in FY 1992.

- Progress During Reporting Period. No progress was required or planned.

- Planned Work for Subsequent Months. None.

- Problem Areas and Actions Taken. None.

- Milestone Status. This task is complete.

\subsubsection{Hot Spot Thermal Modeling}

Radioactive materials decaying in Hanford Site waste tanks generate heat. An early concern, raised when the ferrocyanide tanks first became a safety issue, was whether an exothermic excursion and local propagation could occur within the ferrocyanide waste if a sufficient concentration of ferrocyanide and a high enough temperature were present. This task examined the available temperature data from the ferrocyanide tanks in order to determine the heat load and temperatures as a function of depth and radial location. Sensitivity and parametric analyses were included to.determine the magnitude of hot spots that would have to exist within the waste to reach propagation temperatures.

Heat load analyses and thermal characteristics were completed for all ferrocyanide tanks in FY 1994 (McLaren 1994a, 1994b). The maximum heat load of any ferrocyanide tank assuming worst-case conditions for soil moisture and thermal conductivity was below $4.2 \mathrm{~kW}$. Nominal heat loads calculated by McLaren (1994a, 1994b) compared very favorably with those calculated independently in 1993 (Crowe et al. 1993). A dryout analysis was also completed and released in FY 1994 (Epstein et al. 1994). The report concluded that ferrocyanide sludge could not dry sufficiently to be chemically reactive during interim storage, either globally or locally. Dryout mechanisms evaluated included global evaporation, removal of liquid by leakage or pumping, boiling as a result of hot spots, and enhanced surface evaporation from hot spots. All activities were completed for this task in FY 1994.

- Progress During the Reporting Period. None.

- Planned Work for Subsequent Months. None.

- Problem Areas and Action Taken. None.

- Milestone Status. This task is complete. 


\subsubsection{Infrared Scanning System}

Infrared (IR) scanning systems are commercially available from numerous vendors. These systems are sensitive to changes of $\pm 0.3^{\circ} \mathrm{C}$ or less under ideal conditions and offer promise for mapping surface temperature profiles in the ferrocyanide tanks. Thermal modeling performed on ferrocyanide tank 241-BY-104 (McLaren 1993) suggested that if hot spots with temperatures of concern are possible, surface temperature differences might be great enough to be detected by infrared mapping.

A position paper on the credibility of hot spots and the need for further IR scanning was issued in April 1993 (Dickinson et al. 1993). Further analyses have been performed to assess potential dryout of the ferrocyanide waste (Epstein et al. 1994). These reports examined potential mechanisms for forming hot spots. Analyses indicate that hot spots are - not credible in ferrocyanide tanks. Based on these analyses, Westinghouse Hanford Company recommended that no further planning be pursued for IR scans for the purpose of detecting hot spots.

- Progress During the Reporting Period. None.

- Planned Work for Subsequent Months. None.

- Problem Areas and Action Taken. None.

- Milestone Status. This task is complete.

\subsection{CONTINUOUS TEMPERATURE MONITORING}

"The temperature sensors referred to above [Recommendation 90-7.1] should have continuous recorded readouts and alarms that would signal at a permanently manned location amy abnormally high temperatures and any failed temperature instrumentation."

This task provides continuous monitoring of presently installed (and operable) temperaturesensing elements for the ferrocyanide tanks. New instrument trees will be connected to the system as they are installed into each tank, resulting in continuous monitoring of temperature in the ferrocyanide tanks. All data are collected automatically at the continuously manned Computer Automated Surveillance System (CASS) Operator Control Station. The monitoring system is independent of the CASS and capable of displaying data to an operator on request. Trend data on selected points are available for display in numeric or graphic form.

The system, which became operational in September 1991, has the capacity to assign alarms for a change in the value of any temperature point. Alarms, if they occur, trigger an audible annunciator and are logged immediately to hard copy. An alarm summary display provides a list of the most recent alarms in order of occurrence. Each alarm can be identified by point and time of occurrence. Operator acknowledgement of the alarm will silence the audible 
annunciator. Signal conditioning and multiplexing are performed locally at each tank. This eliminates the need to transmit low-level signals to the tank farm boundary and reduces cable runs. Electronic noise, extension wire corrosion, and thermal gradients are also reduced.

- Progress During Reporting Period. All ferrocyanide tanks are connected to the TMACS for temperature monitoring. Twenty-three instrument trees in.the 18 ferrocyanide tanks are now being monitored continuously by TMACS. Three newlyinstalled instrument trees remain to be connected to TMACS; no new trees were connected this quarter. The TMACS installation design was completed last fiscal year for these new trees.

- Planned Work For Subsequent Months. Connection of new instrument trees to TMACS will be made as soon as practical after the trees are installed.

- Problem Areas and Action Taken. None.

- Milestone Status.

- September 30, 1995. Westinghouse Hanford Company completes TMACS connections for all installed instrument trees in remaining ferrocyanide tanks. This closes out DNFSB Recommendation 90-7.2 and also completes Tri-Party Agreement Milestone M-40-02.

\subsection{COVER GAS MODELING}

"Instrumentation should also be installed to monitor the composition of cover gas in the tanks, to establish if flammable gas is present."

\subsubsection{Interim Flammable Gas Monitoring}

The effort to conduct flammable and toxic gas monitoring and analyses in the ferrocyanide tanks is continuing. Most of this effort was transferred to the Tank Vapor Issue Resolution Program, which is coordinating interim gas monitoring of the ferrocyanide tanks, as well as those tanks involved with the tank vapor program. Tank dome spaces are measured for flammability using a commercial combustible gas monitor (calibrated with pentane gas), and are monitored for potential toxic gases using an organic vapor monitor and Dräger ${ }^{1}$ tubes. Development and validation of alternative technologies for dome space characterization are in progress using sorbent tubes placed on the end of tubes lowered into the dome space and SUMMA ${ }^{2}$ canisters that collect gas samples topside. The initial dome space sampling was

'Trademark of Drägerwerk Aktiengesellschaft, Inc., Lubeck, Germany; also National Draeger, Inc., Pittsburgh, Pennsylvania.

${ }^{2}$ Trademark of Molectrics, Inc., Cleveland, Ohio. 
done in several tank locations (i.e., from two widely separated risers) and at three elevations in the dome space. Reviews of sampling data and modeling (Wood 1992, Claybrook and Wood 1994, Postma et al. 1994b) indicate that the vapor space is well mixed and that sampling from one riser at one elevation is adequate.

- Progress During Reporting Period. Vapor samples were taken from seven tanks this quarter, 241-BY-103, -BY-107, -BY-108, -BY-110, -BY-111, -BY-112, and TX-118. Ammonia concentrations in the tanks, measured via ammonia sorbent traps, were 27, 970, 1040, 401, 63, and 61 parts per million, respectively, for the BY tanks. Results were not available at the end of the quarter for the other gases nor for tank 241-TX-118. The flammable gas readings measured in these tanks were less than $3 \%$ of the lower flammability limit. Supplied breathing air is currently required for areas in the BY Tank Farm and this requirement will continue to be enforced based on the high ammonia results.

All eighteen tanks on the Ferrocyanide Watch List have been vapor sampled, but not all have been sampled using the heated sampling tubes and the mobile vapor sampling laboratory. Selected gas monitoring will continue, as required, to support tank farm operations. Table A-2 in Appendix A reviews results that were available from the gas analyses completed through the end of this quarter.

- Planned Work For Subsequent Months. Flammable gas sampling and selected noxious gas monitoring will continue, as required, to support planned auger and core sampling, instrument tree installation, and the Tank Vapor Program. All ferrocyanide tanks are scheduled to be sampled at least once with the water-heated sampling probe.

- Problem Areas and Actions Taken. None.

- Milestone Status

- September 30, 1995. Westinghouse Hanford Company completes dome space sampling of remaining ferrocyanide tanks. Completion of this milestone closes out DNFSB Recommendation 90-7.3. This milestone also addresses Tri-Party Agreement Milestone M-40-03 scheduled for completion by November 30, 1995.

\subsubsection{Continuous Gas Monitoring}

The possibility that localized concentrations or stratification of gases exist in the tanks has been evaluated. A modeling study to determine airflow patterns in the dome space of tank 241-C-109 was conducted to evaluate the amount of mixing and the local gas concentrations that could occur. The study revealed that the gases in the tank are well mixed and follow Graham's law for gaseous diffusion; therefore, an analysis of a second tank was considered unnecessary because of the well-mixed environment calculated for 241-C-109 
(Wood 1992). Studies completed since that time (Claybrook and Wood 1994, Postma et al. 1994b) also confirm that conclusion.

The need for continuous gas monitoring was addressed in a report that also assessed the potential for cyclic venting and the possibility of accumulating flammable gases (Fowler and Graves 1994). The report concluded that continuous flammable gas monitoring in ferrocyanide tanks is not warranted based on (1) the low concentration of flammable gases found to date; (2) anticipated low ferrocyanide concentrations because of waste aging; (3). analytical results from tanks $241-\mathrm{C}-109$ and -112 showing that the fuel concentration in the tanks is much lower than postulated by flowsheet values and operating records; and (4) calculations of hydrogen accumulation using realistic generation values and passive ventilation assumptions. No further activities are planned in this task.

- Progress During Reporting Period. DOE has concurred that no continuous gas monitoring is required (O'Leary 1994).

- Planned Work For Subsequent Months. This task is complete.

- Problem Areas and Actions Taken. None.

- Milestone Status. None

\subsection{FERROCYANIDE WASTE CHARACTERIZATION}

"The program of sampling the contents of these tanks should be greatly accelerated. The proposed schedule whereby analysis of two core samples from each single-shell tank is to be completed by September 1998 is serioushy inadequate in light of the uncertainties as to safety of these tanks. Furthermore, additional samples are required at several radii and at a range of elevations for the tanks containing substantial amounts of ferrocyanide."

Characterization of the waste in the ferrocyanide tanks is necessary to (1) guide further chemical reaction studies with the ferrocyanide waste simulants; (2) determine actual waste chemical and physical properties; (3) determine how the ferrocyanide waste can be safely stored in situ, and classify the tanks by safety category accordingly, until retrieval and disposal actions are completed; and (4) apply the study results to the final remediation of the waste. This information is necessary to resolve the Ferrocyanide Safety Issue.

The important reactive materials present in the ferrocyanide tanks are fuel (ferrocyanides, sulfides, and reduced carbon species such as organic complexants), oxidants (nitrates and nitrites), and inerts or diluents (including phosphates, aluminates, sulfates, carbonates, oxides, and hydroxides). The location of fission products such as ${ }^{137} \mathrm{Cs}$ and ${ }^{90} \mathrm{Sr}$ is important because these products are heat sources and potential source terms in postulated radiological releases from a hypothetical ferrocyanide reaction. The water content of the waste is very important because water's high heat capacity and heat of vaporization make it an effective 
inerting material. Water can prevent a sustained combustion or a propagating reaction; wet ferrocyanide material would require drying before it could react or propagate.

\subsubsection{Core Sampling and Analyses}

Core Sampling. Both rotary-mode and push-mode core sampling capabilities will be used to obtain core samples from the Watch List tanks. Tanks without saltcake and with relatively soft waste solids can be core sampled by the push-mode method. If a hard saltcake layer is present, rotary-mode core sampling will be used. The first ferrocyanide tank scheduled for rotary-mode core sampling is 241-BY-106; sampling began in this tank using the rotary mode truck in November 1994.

Each core consists of several 48-cm segments (or portions thereof) depending on the depth of the waste in the tank. The sludge layer in these cores will be divided into four $12-\mathrm{cm}$ subsegments for each 48-cm segment. If the tank contains a saltcake layer, the saltcake segments will be divided into only two subsegments. Process flowsheet knowledge, tank historical data, and results obtained from tests with ferrocyanide sludge simulants are used to supplement the analytical results from core sampling.

The priority for sampling ferrocyanide tanks has been changed to reflect the need to determine the reactive properties of the contents. In response to DNFSB

Recommendation 93-5 (DOE 1994a) to expedite sampling and analyses required to address safety issues in the Hanford Site Watch List tanks, the analysis plans for future ferrocyanide tank core samples (and the plans for other Watch List tanks) have been revised. The Watch List tanks have been given priority for core sampling, and the number of required analytes was reduced and refocused on safety-related properties.

- Progress During Reporting Period. Approval was received from DOE (Sheridan 1994b) in November 1994 to remove two tanks, 241-BX-102 and -106, from the Ferrocyanide Watch List based on safety documentation provided earlier (Alumkal 1993, Borsheim et al. 1993). Four other tanks (241-BX-110, -BX-111, -BY-101, and $-\mathrm{T}-101$ ) were previously removed in July 1993 (Anttonen 1993). Eighteen ferrocyanide tanks remain on the Watch List.

As reported earlier (Meacham et al. 1994b), push-mode core sampling of tanks 241-C-108 and -111 yielded poor sample recovery (less than 25 vol\%). However, visual inspection of the waste recovered indicated that the waste in these tanks is viscous, and retains its shape after extrusion. Because of the difficulty in obtaining adequate push-mode core recovery, these tanks were scheduled for auger sampling. Auger sampling in tank 241-C-108 was completed from two risers (4 and 7) in November 1994. A $50.8 \mathrm{~cm}$ (20 in.) auger was used in Riser 4. Two augers [a $25.4 \mathrm{~cm}$ (10 in.) and $50.8 \mathrm{~cm}$ (20 in.)] were used in Riser 7 because the waste was mistakenly calculated to be about $71 \mathrm{~cm}$ ( 28 in.) deep. In reality the waste under both risers was about $48-51 \mathrm{~cm}$ deep. Recoveries were very good (approaching 
$100 \%$ ) except for the first auger sample in Riser 7 which yielded about $33 \%$. Analyses are now in progress with the 45-day screening report due in January.

Auger samples were also obtained from two risers (1 and 12A) in tank 241-BY-108 in late December. Only the top $20 \mathrm{~cm}(8 \mathrm{in}$.) of the saltcake were sampled in order to determine if organic materials are present which would account for the higher-thanexpected vapor concentrations measured when the tank was vapor sampled (see Table A-2, Appendix A). Sample recoveries from the two risers, 1 and 12A, based on the $20 \mathrm{~cm}$ sample depth were $15 \%$ and $30 \%$, respectively. The samples are being analyzed with the 45-day report due in February 1995.

Rotary mode core sampling commenced in Riser 10B of tank 241-BY-106, a $6.1 \mathrm{~m}$ (20 ft.) deep saltcake tank, in November. Segment recoveries varied from 0 to 95 vol\%, with most at the low end. Surprisingly, all 13 segments appeared to be saltcake. Based on historical records the last three to four segments were expected to be sludge that originated from the U-Plant ferrocyanide scavenging flowsheet. A decision was made to repeat the rotary mode sampling in the same riser using information learned during the first attempt. Plugging of the sample hole in the drill bit was encountered for several of the sections, and it is believed that the plugging caused incomplete recovery. This tank has not been interim stabilized and the waste was very moist, similar in consistency to a snow cone slurpy. A decision on what analyses will be performed on the second set of samples will be made after the segments are extruded in the hot cell. Sampling in the second riser will not be attempted until better recovery is possible.

- Planned Work For Subsequent Months. Tank 241-C-111 auger sampling scheduled earlier for this quarter will be started in January. Auger sampling of 241-TY-104 is also scheduled for next quarter. If recoveries are acceptable from rotary mode core sampling in Riser 10B in 241-BY-106, cores from the second riser (5) will be secured. The next ferrocyanide tanks scheduled for rotary mode core sampling during FY-1995 are 241-BY-105, -BY-104, -BY-110, -BY-108, -TY-103, -BY-112, $-\mathrm{BY}-103,-\mathrm{TY}-101,-\mathrm{BY}-107$, and $-\mathrm{BY}-111$.

- Problem Areas and Actions Taken. Rotary-mode sampling of ferrocyanide tank 241-BY-106 encountered varying degrees of segment recovery. Lessons learned from the first core sampling using the rotary-mode truck will be applied to a second set of core segments in the same riser (10B). The waste was primarily saltcake and very moist. It is expected that the waste filled back into the hole created by the drill string and that repeat sampling should secure representative waste from a given elevation within the tank. Core sampling from the second riser (5) will not be attempted until better recoveries are achieved. 
- Milestone Status.

- October 31, 1994. Westinghouse Hanford Company secures rotary-core samples from ferrocyanide tank 241-BY-106. Thirteen core segments were attempted in this tank from one of two risers to be sampled. Sampling from the second riser will not be started until better segment recoveries are demonstrated by repeat sampling in the first riser or in another tank.

- June 30, 1995. Westinghouse Hanford Company obtains core and/or auger samples from four ferrocyanide tanks. Two full-depth auger waste samples were obtained from tank 241-C-108 this quarter. Two surface (20 cm deep) auger samples were also obtained from tank 241-BY-108. This milestone remains on schedule.

- September 30, 1995. Westinghouse Hanford Company completes data interpretation reports, available for public release, for four ferrocyanide tanks. The data interpretation reports for tanks 241-C-108 and 241-C-111, in addition to the existing data reports on tanks 241-C-109 and 241-C-112 (Simpson et al. 1993a, 1993b), will help provide the technical basis for recommending that the Ferrocyanide Safety Issue be resolved for the four C Farm tanks.

- December 31, 1995. Westinghouse Hanford Company obtains core samples from five additional ferrocyanide tanks.

- March 31, 1996. Westinghouse Hanford Company completes data interpretation reports, available for public release, for five ferrocyanide tanks.

- July 31, 1996. Westinghouse Hanford Company obtains core samples from the remaining ferrocyanide tanks.

- October 31, 1996. Westinghouse Hanford Company completes data interpretation reports, available for public release, for the remaining ferrocyanide tanks.

Fourier Transform Infrared Spectroscopy Analyses. FTIR spectroscopy is rapidly becoming the method of choice for demanding applications such as in situ and remote characterization of highly toxic and hazardous materials. Recent developments in FTIR-based fiber optic spectroscopy have provided a new methodology to chemically characterize ferrocyanide-bearing waste. Chemometrics and microprocessors that allow storage and rapid analyses of data have contributed significantly to the development of state-of-the-art fiber optic probes.

- Progress During Reporting Period: An assessment of the performance of the FTIRFiber Optics technique to characterize archived tank waste core samples for water, ferrocyanide, and organic species was started in FY 1994. Tests were conducted in 
the near-infrared (NIR) region of the light spectrum because radiation-resistant, midinfrared-transparent optical fibers were not commercially available.

Two bifurcated fiber optic probes made of very low-OH fused silica fibers were used to examine the infrared absorption signatures of several archived core samples. One probe consisted of 7 silica fibers while the other contained 496 silica fibers. Both fiber probes were designed and fabricated to satisfy fundamental specifications for diffuse/specular reflection spectroscopy in the NIR region.

Aliquots of archived core samples from three non-ferrocyanide single-shell tanks, 241-B-202, -T-104, and -T-105, were measured for their NIR absorption characteristics because samples from ferrocyanide tanks were not available at the time. Samples from ferrocyanide tanks 241-BY-106 and -C-108 will be analyzed next quarter. Figure 3-1 displays the NIR spectra of "as received" and "air-dried for one week" samples. All spectra were recorded using the 7-fiber probe positioned $1 \mathrm{~mm}$ above the sample. Care was taken so the probe did not touch the sample to avoid cross-contamination as different samples were analyzed.

As seen in Figure 3-1, the spectra of "as received" samples are dominated by strong absorption of water molecules $\left(5215 \mathrm{~cm}^{-1}\right.$ and $7000 \mathrm{~cm}^{-1}$ bands). The general shape of these spectra resembles closely those obtained for wet simulated T-Plant, U-Plant, and In-Farm sludges studied earlier (Rebagay et al. 1994).

Spectra of the air-dried samples show loss of free water as indicated by the significant reduction of the absorbance of water at $7000 \mathrm{~cm}^{-1}$. In addition, partial removal of water reveals several sharp bands in the $7200 \mathrm{~cm}^{-1}-6400 \mathrm{~cm}^{-1}$ region of the 241-T-105 waste spectrum. This strongly suggests the presence of organic species in this sample. Tank 241-T-105 is not presently listed as an organic tank. These results will be compared with the analytical results reported in the characterization report for this tank.

These qualitative results show clearly that the FTIR-Fiber Optics method is capable of detecting infrared-active organic and inorganic species in tank waste core samples.

- Planned Work For Subsequent Months. The molecular characterization of archived tank waste core samples using FTIR-Fiber Optics technique will continue. Core samples containing water, ferrocyanide, and organic species will be studied in greater detail using infrared microscopy. The infrared microscope combines microscopy with infrared spectroscopy to provide a versatile instrument for molecular microanalysis. The utility of a new melt film sample preparation technique (Fischer and Bader 1994) coupled with grazing angle microscopy (Reffner et al. 1991) for the quantitative determination of ferrocyanide and organic species in core samples will be investigated.

- Problem Areas and Actions Taken. None. 
Figure 3-1. FTIR Spectra of Hanford Site Mixed Waste from Three Tanks
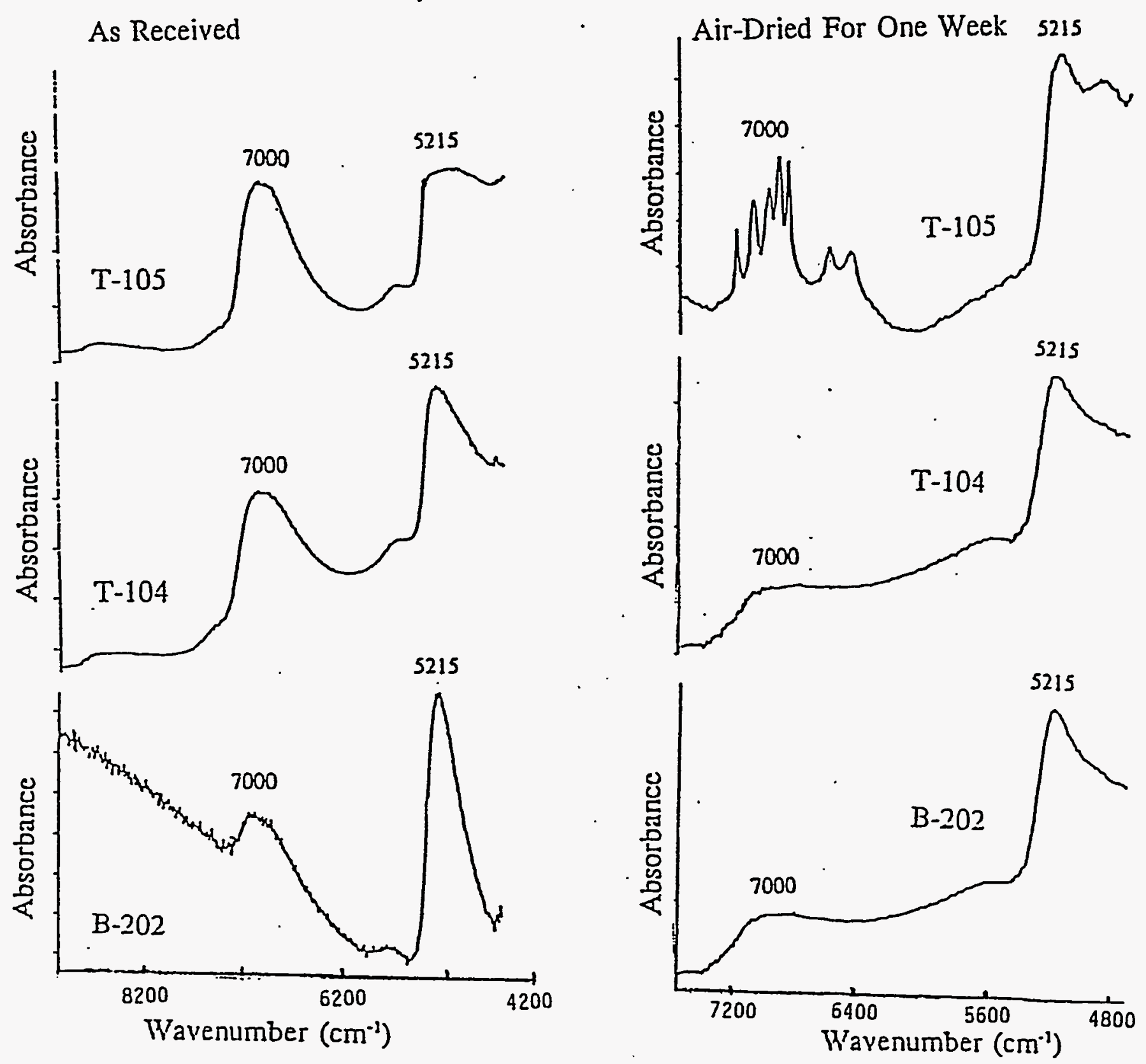
- Milestone Status.

- September 30, 1995. Westinghouse Hanford Company issues a final report on FTIR technology development and demonstration for determination of water, ferrocyanide, and organic species.

Mossbauer Spectroscopy. A small task on Mossbauer spectroscopy is investigating the physical and chemical nature of iron within ferrocyanide tank waste. NASA recently. developed a miniaturized Mossbauer spectrometer that is small enough to perform elevation scans in the LOWs.

Mossbauer spectroscopy can yield information about the valence state of iron as well as information on the specific coordination chemistry. A recent development in this type of spectroscopy is the use of reflectance rather than transmission spectroscopy, thus allowing information to be gained in situ rather than having to use waste samples from the tanks. Mossbauer spectroscopy can distinguish between ferrocyanide and ferricyanide complexes and almost any iron compound that might exist within tank waste. By knowing the iron concentration and species as a function of elevation in a given tank, it should be possible to determine how much aging has occurred within the waste.

The Mossbauer program represents a cooperative venture between Westinghouse Hanford Company, DOE, and NASA. The contact at NASA is Dr. Richard Morris at the Johnson Space Center in Houston, Texas.

- Progress During Reporting Period. Five different ferrocyanide waste simulants were sent to Dr. Morris of NASA at Houston, Texas for analysis using the miniature Mossbauer spectrometer. Initial results indicate that all of the simulants have different Mossbauer spectra making it easy to distinguish among the samples.

Contract negotiations are in the final stages of approval between NASA and Westinghouse Hanford Company in order to procure a miniature spectrometer for use at the Hanford Site and for providing technology transfer between sites. The contract is expected to be finalized by mid-February.

- Planned Work for Subsequent Months. A meeting has been scheduled to meet with Dr. Morris of NASA on January 24 to 27, 1995 to work on the probe for hot cell testing at the Hanford Site. A hot cell test using actual tank waste is tentatively scheduled to start in April 1995. A tank expected to contain significant quantities of iron leftover from ferrocyanide additions will be selected for Mossbauer spectrometer scans in the LOW. Additional tanks will be scanned after initial results are analyzed.

- Problem Areas and Actions Taken: None. 
- Milestone Status.

- April 30, 1995. Westinghouse Hanford Company initiates hot cell testing 'of the Mossbauer tank probe using ferrocyanide tarik waste samples.

- July 31, 1995. Westinghouse Hanford Company completes an in-tank test of the Mossbauer probe in an LOW in one of the ferrocyanide tanks.

- September 30, 1995. Westinghouse Hanford Company issues a report, available for public distribution, on the Mossbauer spectroscopy program results. for FY 1995.

Scanning Electron Microscopy. Information concerning the physical and chemical properties of ferrocyanide tank waste is being obtained to accurately assess the wastes for safety and inventory purposes. Analyses indicating the presence or absence of key chemical components--including $\mathrm{CN}^{-}, \mathrm{Na}, \mathrm{Fe}, \mathrm{Ni}$, and $\mathrm{Cs--can}$ be used to characterize the tank waste and to assess whether the waste can be stored safely until retrieval for final disposal. Measurements that allow examination of possible correlations of chemical composition and physical properties, such as particle and crystallite size, may provide additional information on how the waste has degraded with time and to compare real waste properties with those obtained earlier from waste simulants.

Scanning Electron Microscopy (SEM) coupled with Backscattered Electron Detection (BSE) and Energy Dispersive X-Ray Spectroscopy (EDX) provide a method uniquely capable of providing particle size, chemical composition, and particle morphology information in a single measurement. Recent developments in instrumentation computer control, digital data acquisition, and light element $\mathrm{X}$-ray detection have significantly enhanced the utility of these technologies for particle characterization applications. Refinements in software and firmware allow rapid collection, processing, and storage of large volumes of chemical and numerical data. These enhancements to the instrumentation provide a new and potentially powerful methodology for the characterization of ferrocyanide tank waste.

- Progress During Reporting Period. Final details for procurement of a computer controlled SEM (CCSEM) system were completed. A contract was awarded to R. J. Lee Group, Inc. for delivery of their Personal Scanning Electron Microscope $\left(\mathrm{PSEM}^{\mathrm{TM}}\right)^{1}$ system, associated hardware and firmware, operational and particle characterization software, and specimen preparation equipment and consumables. The PSEM ${ }^{\text {TM }}$ system is scheduled to be shipped to the Hanford Site in February 1995.

Particle characterization software was acquired for installation on the PSEM ${ }^{\text {TM }}$ system currently located in the Environmental Analytical Laboratory (EAL), a non-rad

${ }^{1}$ PSEM is a registered trademark of the R. J. Lee Group, Inc., Trafford, Pennsylvania. 
facility operated by IT Hanford Company in the 100N Area. The EAL PSEM ${ }^{\mathrm{TM}}$ is essentially identical to the CCSEM being acquired for tank waste characterization. This software acquisition allows preliminary tests and protocol runs to be performed on the EAL PSEM ${ }^{\mathrm{TM}}$. The particle characterization software training and experience performed on the EAL PSEM ${ }^{\mathrm{TM}}$ will be directly transferable to the PSEM ${ }^{\mathrm{TM}}$ system for the tank waste characterization effort.

- Planned Work For Subsequent Months. Preshipment acceptance tests will be performed at the vendor's facilities during the first week in February 1995. After acceptance, the unit will be shipped to the Hanford Site for installation in a facility equipped to handle radioactive materials. Final arrangements will be made for location and placement of the PSEM ${ }^{\mathrm{TM}}$ system.

Arrangements for shipping and handling of radioactive waste samples and for specimen preparations in the CCSEM facility will be completed. Procurement of specimen preparation equipment required for SEM particle characterization will be completed.

- Problem Areas and Actions Taken. The initial location planned for the CCSEM facility has become marginally acceptable because of the physical layout and economic factors. The current fall-back position is to install the PSEM ${ }^{\mathrm{TM}}$ system temporarily in the $622 \mathrm{G}$ Building at the Hanford Weather Station complex until a final decision is made on a location capable of accommodating radioactive samples.

- Milestone Status.

- May 31, 1995. Westinghouse Hanford Company installs and completes operational acceptance tests on the CCSEM system.

- September 29, 1995. Westinghouse Hanford Company issues a report, available for public release, on SEM program results for FY 1995.

\subsubsection{Estimation of Moisture Content}

Methods for determining moisture concentrations in ferrocyanide waste tanks are being developed using sample data analyses and available surveillance systems. This is an increase in scope from the original implementation plan (Cash 1991), which did not examine moisture monitoring. Two in situ moisture monitoring technologies are currently being investigated by the Ferrocyanide Safety Program: neutron diffusion and EMI. Initial development of near-infrared spectroscopy at the Center for Process Analytical Chemistry (CPAC), University of Washington was completed in FY 1994. This surface moisture monitoring technology will not be developed further by the Ferrocyanide Safety Program. Additional moisture monitoring technologies, such as copper foil activation, fission chamber in a cone 
penetrometer, are being evaluated by other programs. A report examining moisture monitoring technologies was completed in April 1993 (Meacham et al. 1993).

Neutron Diffusion. Well-logging techniques, coupled with computer modeling, were developed and applied to an existing neutron probe to determine information about moisture levels, material interfaces, and other waste characteristics in the ferrocyanide tanks. Using the knowledge gained from computer modeling, in situ measurements, and experimental calibration data with the current in-tank neutron probe (Watson 1993), prototype moisture measurement neutron probes were developed. This system consists of three neutron probes: a near-field thermal neutron probe, a far-field thermal neutron probe, and a far-field epithermal neutron probe. This improved system would primarily be used to determine the axial moisture concentration profile within the ferrocyanide tanks.

Moisture measurement using neutron diffusion is an established technology. The technique uses a neutron source and one or more neutron detectors. The thermal neutrons reaching a detector originate as fast neutrons from the source and are slowed or absorbed by the medium. Because hydrogen atoms are effective at slowing down neutrons, the detector response is a strong function of the surrounding moisture concentration.

Two methods are generally used in the measurement of moisture concentration around wells using neutron diffusion. The first method, the moisture gauge, has a short source-to-detector spacing (near-field) on the order of 0 to $6 \mathrm{~cm}$. The response of a moisture gauge is characterized by an increase in detector response with increasing moisture concentration of the surrounding medium. The second method, the neutron log, often has two detectors with longer source-to-detector spacings: 20 to $50 \mathrm{~cm}$ (far-field). The detectors in a neutron $10 \mathrm{~g}$ arrangement exhibit a decreased response to increased moisture concentrations. The detector placed at the shorter spacing is used to correct the response of the longer-spaced detector for borehole effects.

The tank moisture measurements are taken from within an LOW. The LOWs are permanently installed sealed pipes that extend from the riser top through the tank waste to near the tank bottom. The LOWs allow axial information about the surrounding waste materials to be obtained using certain detectors.

- Progress During Reporting Period. In-situ tank measurements have been obtained in nearly all ferrocyanide Watch List tanks containing an LOW using the prototype neutron moisture probes. The results of these tests indicate the system is functional in the waste tank environment. Complete analyses of the tank scan data to produce bestestimate moisture concentration profiles of the tank waste will be delayed until the system can be fully calibrated. Scans were taken with each probe without the neutron source attached to confirm that no gamma interference was encountered in the data.

A computer code is being written to automatically read in the available data from moisture measurement probes, to correlate the data to responses expected from different possible material anomalies and moisture contents, and to provide a best 
estimate moisture profile interpretation. Input to the code will be based on computer modeling results of expected probe responses and on measured calibration data using moisture simulants.

Based on computer modeling and tests measurements using the prototype probes, two final field unit probes, thermal and epithermal, were designed and are now being fabricated. These field unit probes will incorporate additional lead shielding for gamma rays, will utilize a sturdier, corrosion resistant housing, and will each contain two detectors for near- and far-field measurements. The electronics for these dual probes will allow for multiplexing of the signals through a single conductor logging cable. The design of these probes should make the moisture calibration more accurate in a high gamma field and reduce the required source handling and data collection times.

Ferrocyanide waste moisture simulants containing 15, 17, and 20 weight percent (wt\%) water have been prepared. The prototype system has not yet undergone a complete moisture calibration because acceptable waste moisture simulants were not available until recently.

A new material and insertion method for liquid observation wells is being developed to enhance the probe responses to the moisture content of surrounding waste (Watson et al. 1994). Material constraints and practical considerations coupled with computer modeling have led to the selection of S-glass fiberglass composites as the LOW material that will be tested for suitability in the tank environment. This material contains no strong thermal neutron absorbers and small quantities of neutron moderators. This material also allow for moisture measurements using an EMI probe. The new method of LOW installation will utilize an ultrahigh-pressure water system as the bottom endplug of the LOW (Hertelendy 1993). This system will make the LOW self-inserting, will greatly reduce the water needed to insert the LOW, and will minimize the production of air- or liquid-filled cavities around the LOW. The installation of these new LOWs is anticipated to begin in FY 1996 to meet single shell tank leak detection requirements and to support moisture concentration monitoring of ferrocyanide and other Watch List tanks.

- Planned Work for Subsequent Months. A moisture concentration waste simulant containing about 25 wt\% water will be prepared. Final calibrations will be performed on the neutron probe prototypes. Computer modeling will be performed to compare calculated predictions with actual measurements. These same computer models will then be adapted to perform tank waste modeling. Results of the tank waste modeling will assist with interpretations of tank scans. The fabrication, testing, and calibration of dual-detector, optimized field probes will be completed. The development of an automated data moisture interpretation routine will continue. New LOW material tests will be performed and the ultrahigh-pressure water installation hardware will be designed and tested. 
- Problem Areas and Action Taken. Collecting field data using the existing antiquated surveillance equipment has been very difficult because of numerous equipment failures and because the surveillance van and equipment were not available. An attempt to acquire a dedicated van with self-contained surveillance equipment has not yet been approved. Several alternatives are being considered that may provide a means for data acquisition during the second half of FY 1995.

\section{- Milestone Status.}

- September 30, 1994. Westinghouse Hanford Company provides a report on a working prototype moisture monitoring neutron probe system. This milestone was completed on schedule (Watson et al. 1994).

- September 30, 1995. Westinghouse Hanford Company completes installation and deployment of the first phase of the neutron moisture monitoring system and initiates monitoring. This milestone is on schedule.

- September 30, 1996. Westinghouse Hanford Company completes installation and deployment of the neutron moisture monitoring system for routine monitoring in ferrocyanide tanks.

Electromagnetic Induction Probe. The purpose of this task is to deploy the EMI probe in the LOWs in order to measure the waste moisture concentration in ferrocyanide and organic Watch List tanks. EMI probes operate by creating a magnetic field that induces current in a conductive medium. This induced current can be measured and is related to the media conductivity. The higher the electrical conductivity, the higher the free moisture content in the tank waste.

The EMI probe is designed with three separate coils of wire: an exciting coil and two sensing coils. The exciting coil is driven with an electric current that creates a magnetic field. This magnetic field induces an electric current in conductive material that creates a secondary magnetic field that creates a voltage in the two sensing coils. The intensity of the induced voltage in the sensing coils is directly related to medium electrical conductivity. The electrical conductivity of the tank waste is related to its free moisture content.

EMI (also called eddy current) inspection is a well-developed technology used in the nuclear, aviation, petroleum, and medical fields. The usual method of EMI. inspection uses differential measurements or variations from a baseline signal. The measurement of conductivity is an absolute measure that requires careful attention to calibration.

There are two areas of engineering activity to apply EMI technology to the measurement of free moisture content in the Hanford Site high-level waste tanks: (1) EMI measurement of absolute conductivity of the waste medium, and (2) determination of the electrical conductivity as a function of the free moisture content of ferrocyanide or organic waste. 
Measurement of absolute conductivity will be studied using finite-element modeling of the EMI probe geometry. The modeling now being performed by Washington State University will also aid in probe design and in interpretation of EMI measured results.

The conductivity of ferrocyanide and organic waste as a function of moisture will be determined initially using representative simulants. The variability will be determined by drying each simulant to different moisture levels. It may be necessary to measure the conductivity of real waste samples if the composition of the waste is a dominant variable.

- Progress During Reporting Period. EMI modeling started this quarter at Washington State University (WSU) under the direction of Dr. Lee Philipp. The WSU finite element code, EDDY-PC, was converted to the LOW geometry in ferrocyanide tanks. EDDY-PC was also converted from personal computer to a WSU mainframe computer to accept the larger numerical matrices needed to model the LOW and ferrocyanide tank geometries. The modified code was compared to test cases, and EMI probe calculations have began. Initial computer results reproduced single-coil probe measurements in air, reproduced the effect of adding coaxial cable to move the EMI electronics away from the top of the tanks, and predicted the effect on impedance and phase due to a conductive medium outside the LOW. The calculated change in impedance and phase for a representative ferrocyanide tank medium conductivity are of a magnitude that can be easily measured, indicating the EMI method can successfully detect conductivity changes and thus the free moisture content in ferrocyanide tank waste.

Thirteen vendors were contacted and their company's literature was acquired. The most promising supplier for EMI equipment is Zetec, the largest EMI company in the world. Zetec facilities in Issaquah, Washington were visited. It was verified that Zetec is a complete EMI service company and can supply electronic EMI equipment and probes and EMI signal interpretation software. The can also design and build special equipment to lower the EMI probe into an LOW to scan for tank moisture measurement.

The Pacific Northwest Laboratory (PNL) will design and build a portable calibration standard for the EMI probe. This will serve as a functionality standard, assuring proper functioning of EMI equipment before and after each tank is scanned. The portable standard will also serve as a moisture calibration unit in the field, near the tanks to be monitored.

Requirements for small-scale calibration standards have been defined. Calibration tests on representative ferrocyanide tank materials will start next quarter to determine the relationship between electrical conductivity and free moisture content of ferrocyanide waste simulant material. This work will be done by the Chemical Engineering Laboratory at Westinghouse Hanford Company. 
- Planned Work for Subsequent Months. EMI probe modeling will continue at WSU with the goal of determining the depth of penetration into the waste that can be surveilled and the sensitivity of EMI to changes in moisture. Portable and laboratoryscale calibration standards will be designed.

Results of the EMI equipment market survey will be documented in a letter report. Specifications will be prepared for procurement of EMI electronics and software. Requirements for portable calibration standards will be defined and procurement of materials will be initiated.

Requirements for small-scale calibration standards will be defined and tests with ferrocyanide simulants will be started in the Chemical Engineering Laboratory using existing EMI coils and with new equipment after it is procured.

- Problem Areas and Action Taken. Approval of the procurement requisition for a dedicated surveillance van that would deploy the EMI probe as well as the new neutron probes is still on hold. Existing surveillance vans are dedicated to routine neutron and gamma scans and usually are available only on an overtime basis. Alternate EMI measurement arrangements at ferrocyanide tanks are being considered.

- Milestone Status.

- May 30, 1995. Westinghouse Hanford Company acquires an EMI system compatible with surveillance van application. If procurement of the surveillance van is not approved, this milestone may need to be redefined.

- September 30, 1995. Westinghouse Hanford Company issues a report, cleared for public release, describing the FY 1995 engineering testing of the EMI moisture monitoring system. The report will describe the equipment and procedures necessary for deployment of the EMI probe in tanks for routine monitoring of moisture levels in ferrocyanide and organic tanks.

\subsubsection{Moisture Retention Properties of Ferrocyanide Simulants}

The moisture content of ferrocyanide sludge is very critical in preventing exothermic ferrocyanide/nitrate-nitrite reactions. Studies are underway to evaluate the moisture retention properties of ferrocyanide simulants as they relate to possible waste tank leaks, tank stabilization by pumping, and possible evaporation from exposed surfaces. Previous work (Epstein et al. 1994) has shown that ferrocyanide sludge cannot dry sufficiently to be chemically reactive during interim storage, either globally or locally. Dryout mechanisms evaluated included global evaporation, removal of liquid by leakage or pumping, boiling as a result of hot spots, and enhanced surface evaporation from hot spots. 
- Progress During Reporting Period. The objective of this effort is to conduct modeling calculations to predict the moisture retaining capability of ferrocyanide wastes in a typical tank system. The modeling studies are based, in part, on physical experiments recently conducted by Westinghouse Hanford Company scientists $\mathrm{C}$. King and J. Relyea to obtain simulant sludge evaporation drying rate data. King (1994) exposed samples of In-Farm-1 and U-Plant-1 ferrocyanide waste simulants, tank 241-BY-104 saltcake simulant and a saturated solution of sodium nitrate to a $30 \%$ constant relative humidity $(\mathrm{RH})$ at $25^{\circ} \mathrm{C}$. The samples were contained in $5.6 \mathrm{~cm}$ deep bottles with an open top exposed to the constant RH. The moisture loss with time was measured over a period of 3000 hours. Both the In-Farm-1 and U-Plant-1 samples progressively dried out to less than $10 \%$ of the total water initially available. The sodium nitrate standard dried completely in a shorter time (about 1800 hours). However, the BY-104 saltcake simulant still retained $80 \%$ of the initially available water after 3000 hours.

This experiment demonstrated that the surface of the ferrocyanide sludge simulants is vulnerable to substantial evaporative drying up to the $5.6 \mathrm{~cm}$ depth. In contrast, considerable mechanical pressure, up to many atmospheres, would be required to consolidate sludge to the same level of dryness. Thus, evaporation is much more effective in removing water from sludge simulants than is consolidation by gravity drainage.

The evaporative flux for this experiment was found to be consistent with diffusion of water out of the sample and decreased smoothly over time as drying of the simulant samples progressed. In contrast, evaporation from the surface of the saturated sodium nitrate solution became constant and held steady over most of the drying period. This demonstrated that movement of water to the sludge surface was slowed relative to the sodium nitrate standard. The U-Plant simulant showed the greatest moisture flux at the beginning of evaporation, probably because the supernatant had the lowest concentration of nitrate salts. The drying process was also influenced, in an undetermined way, by the movement and precipitation of high salt concentrations in the supernatant. The growth and accumulation of salt crystals at the surface were observed.

Relyea (1994) measured the RH drying isotherms for In-Farm-1 and U-Plant-1 simulants, as shown in Figure 3-2. Isotherms at constant temperature were obtained by measuring the equilibrium $\mathrm{RH}$ over samples dried to various moisture contents. The RH measurements were made using an activity meter which uses a chilled mirror with a photodetector to determine the dewpoint temperature and to yield relative humidity over or near the surface of a small, isolated sample. The instrument was checked and calibrated against RH standards for all measurements. The $0.5 \mathrm{~cm}$ thick samples were dried by exposure to four different levels $(85 \%, 76 \%, 62 \%$, and $32 \%$ ) of constant RH in closed containers. The constant RH levels were established within the atmospheres of the closed containers by saturated solutions of various salts: $\mathrm{KCl}$, $\mathrm{NaCl}, \mathrm{NH}_{4} \mathrm{NO}_{3}$, and $\mathrm{MgCl}_{2}$, respectively, in the bottom of the container. Beyond the 
loss of the first 40 to $50 \%$ of the available water, the isotherms were different, and dependent on the RH exposure level. The RH was lower at a particular moisture content for samples exposed to lower RH conditions.

Relyea also found that the re-wetting isotherm (not shown in Figure 3-2) for dried simulants occurred at much higher RH than the drying curve. Thus, sludge simulants will adsorb water back if exposed to $\mathrm{RH}$ higher than the equilibrium value. The hysteresis behavior displayed by the $\mathrm{RH}$ isotherms indicates that the physical-chemical nature of the sludge simulants is irreversibly altered by drying below the moisture content where salts precipitate from the sludge. It is thought that the sodium nitrate and nitrite concentration mainly determines the RH isotherm. However, the simulant solids further reduce the equilibrium $\mathrm{RH}$ along the drying isotherm, indicating a stronger water retention capability for sludge that has not been previously dried.

The RH isotherms exhibited a salt precipitation-type transition for which the $\mathrm{RH}$ remains nearly constant over an interval of changing moisture content. An analytical curve with common characteristics for different exposure levels was found to fit the measurements shown in.Figure 3-2. Using the curves helps smooth the measurement variation and provides a means for introducing the information into modeling calculations of evaporation based on vapor pressure gradient.

These isotherms are used for calculating the RH gradient between the samples and air which is likely the cause for the evaporation as measured in King's experiment. The measurements are being used to test the appropriate physical theory for describing the evaporation from sludge.

In a standard analysis of the drying measurements, drying was found to behave similar to a liquid diffusion process. By expressing the simulant sample moisture content in terms of a relative available moisture variable, a common character for the drying process could be determined.

The relative available moisture content is the water content less the final equilibrium value, which is achieved after exposure to a constant $\mathrm{RH}$, divided by the difference between the initial and final water content. This variable is also the maximum

percent loss of available moisture less the present percent loss of available moisture divided by the maximum and is also called the "unaccomplished moisture change" in standard drying analysis.

Figures 3-3 and 3-4 show the drying curves obtained for both experiments by King and Relyea. The measurements, transformed to relative available moisture content, are plotted on a semilog scale. In Figure 3-3, the drying of saltcake displays a pattern that is definitely different from that of the simulant sludges. The relative drying rate slows after an initial period of more rapid evaporation than the other samples. This is seen in the abrupt change of slope. However, the drying curves for 


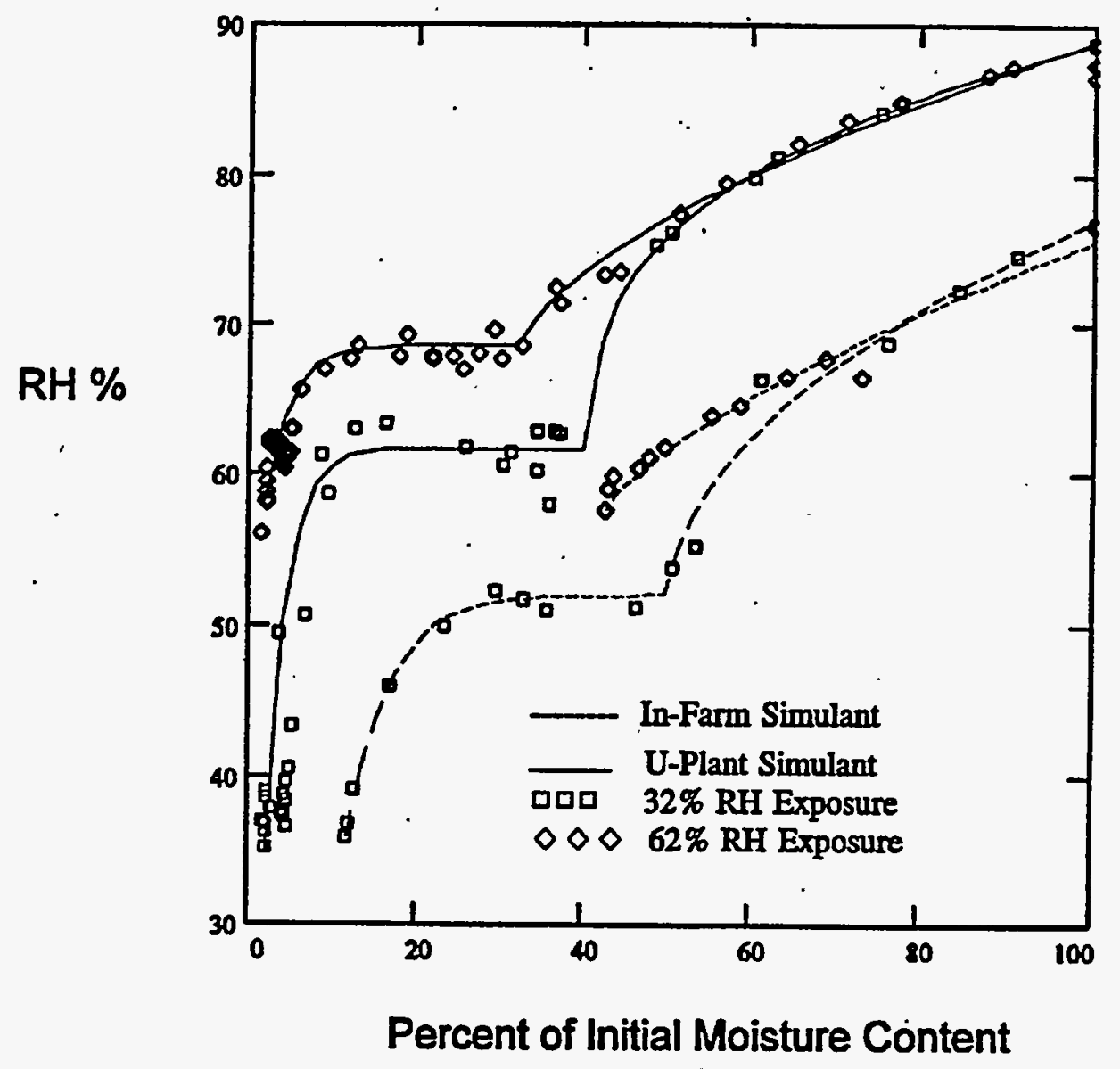

Figure 3-2. Relative Humidity (RH) Isotherms for Sludge Simulants After Exposure to RH Levels of $32 \%$ and $62 \%$. Data from Relyea (1994). Curves are a common analytical equation fit to the data.

samples. This is seen in the abrupt change of slope. However, the drying curves for the sludge simulants are similar to that of the saturated sodium nitrate solution, except that the salt saturated solution dries out sooner. The slopes for the sodium nitrate solution and In-Farm simulant are nearly the same, suggesting that the sludges are, at least initially, drying mainly on the surface.

If the drying curves for U-Plant simulant in Figure 3-4 were plotted in terms of only percent loss of available moisture, they would be quite distinct for different $R H$ exposures. The transformation to relative available moisture brings the curves together and demonstrates that a similar evaporation process is occurring.

If a simple diffusion-like process acted during the entire drying period, the curves would be nearly straight lines, except at the beginning. The curves shown in Figures 3-3 and 3-4 appear to have two dominant, approximately linear, parts with an abrupt change in slopes representing a transition in the liquid diffusion coefficients. There 


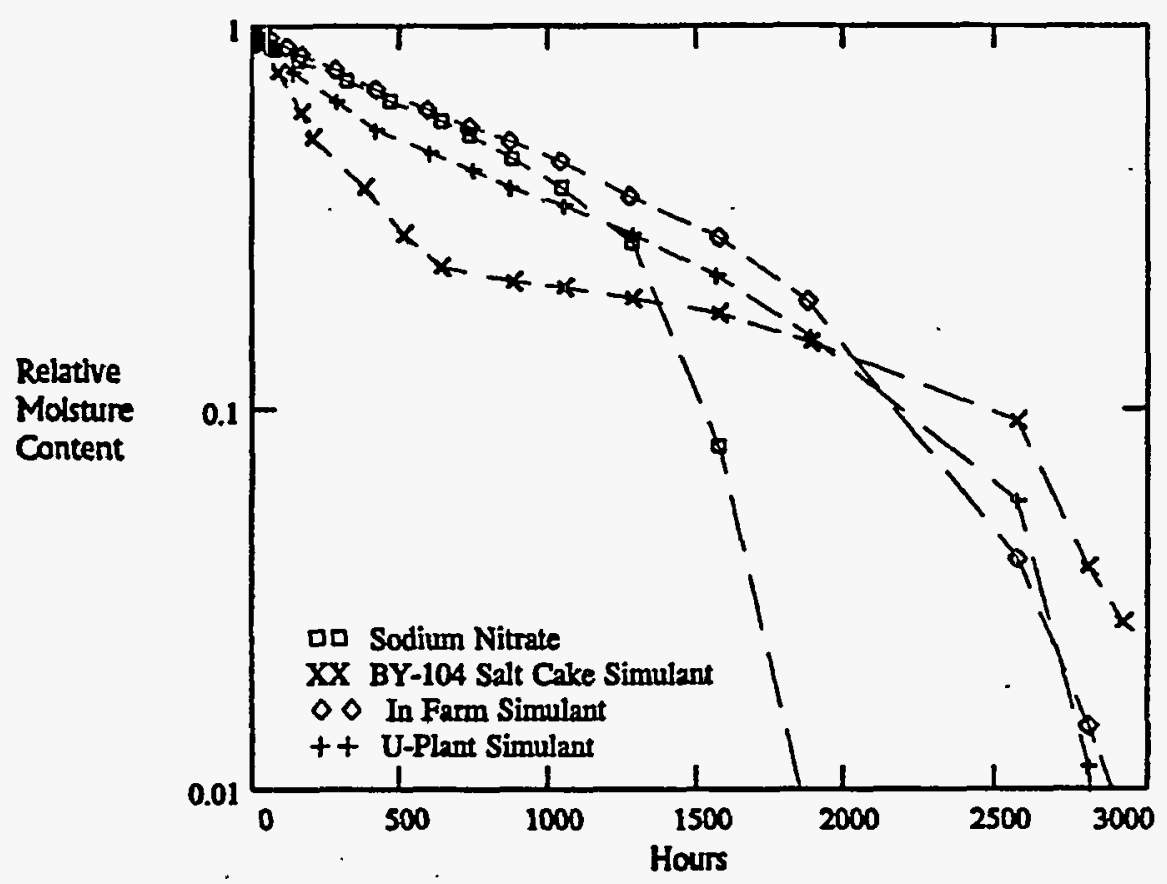

Figure 3-3. Relative Available Moisture Content for Drying Experiment of King (1994). Maximum moisture loss for U-Plant and In-Farm ferrocyanide simulants was estimated from drying measurements of Relyea (1994) at 32\% RH.

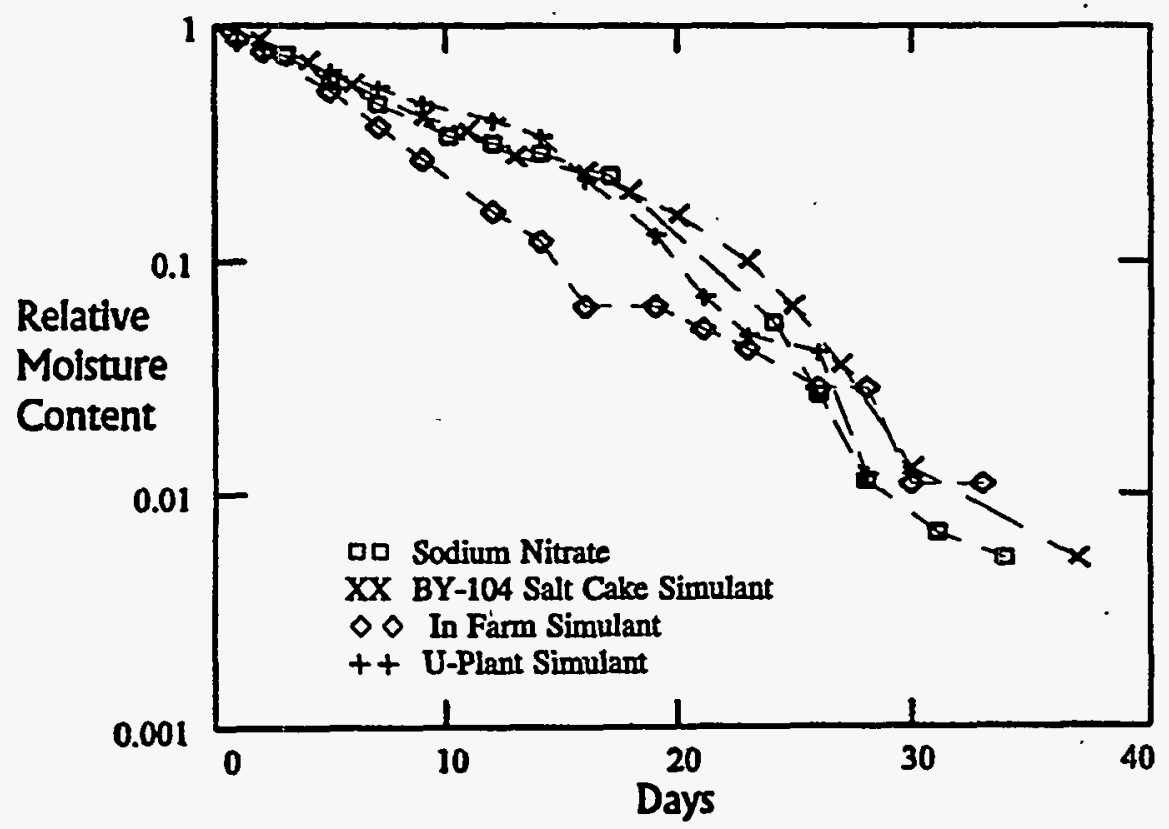

Figure 3-4. Relative Available Moisture for U-Plant Simulant Exposed to Four Levels of Constant Relative Humidity. Data from Relyea (1994). 
was no apparent initial period of constant-rate evaporation that commonly occurs in the drying of wet materials.

This constant-rate evaporation behavior, however, was exhibited by the free-surface evaporation of saturated sodium nitrate solution. Based on the simulant drying curves seen in both figures, the evaporative flux begins to decline immediately.

According to basic theory, the time constant for the exponential decrease of relative moisture is proportional to the square of sample thickness divided by the apparent diffusion coefficient. This fact was used to estimate diffusion coefficients. Those values for the $5.6 \mathrm{~cm}$ deep bottles compared to the $0.5 \mathrm{~cm}$ thick samples used in the Relyea measurements were about 30 times greater.

This result indicates that the apparent diffusion coefficient is not an inherent property of the sludge simulant, but it reflects the flow dynamics and the system's length scale. Because the experiments only measure the composite evaporation process, it is not certain that the diffusion coefficients could represent the detailed moisture flux within the samples, as based on Fick's Law. Nevertheless, only two diffusion coefficients and a dividing point between approximate linear parts of the drying curves are needed to describe the evaporation for all samples.

The drying of In-Farm simulant was found to follow the same pattern as the U-Plant simulant shown in Figure 3-3. By scaling the drying time for the In-Farm sludge simulant, the drying curves for both sludge simulants can be made coincident when exposed to $32 \%$ or $62 \%$ RH. This result further confirms a similar progression of liquid diffusion in both sludges during drying. It demonstrates that the two sludges dry in a similar way.

- Planned Work for Subsequent Months. Modeling of the drainage properties of waste, especially saltcake, will continue. Experiments will be conducted at FAI to measure sludge consolidation and water loss from saltcake as a function of water evaporation by exposure of simulant materials to varying relative humidities in an enclosed chamber. The quantitative information from these experiments will be used to develop models in FY 1995 for evaluating moisture retention in tank waste. Ultimately, the objective is to estimate how fast and how much water could evaporate from sludge and/or saltcake if exposed to tank atmospheres with relative humidities lower than about $75 \%$.

- Problem Areas and Actions Taken. None.

- Milestone Status.

- September 30, 1994. Westinghouse Hanford Company completes drainage tests on ferrocyanide waste simulants and issues a publicly available report on modeling and moisture retention of ferrocyanide sludge. This effort was combined with the hot 
spot task (Section 3.1.3) to produce a comprehensive report on ferrocyanide sludge dryout (Epstein et al. 1994). This milestone was completed on schedule.

- September 30, 1994. Westinghouse Hanford Company issues a publicly available report on the effects of relative humidity on moisture retention in ferrocyanide waste and saltcake. A report was released last quarter, on schedule (King 1994).

- September 29, 1995. PNL issues a report, cleared for public release, on FY 1995 work on waste moisture modeling activities.

- September 30, 1995. Westinghouse Hanford Company issues a publicly available report evaluating water loss from sludge and saltcake as a function of relative humidity.

\subsection{CHEMICAL REACTION STUDIES}

"The schedule for the program on study of the chemical properties and explosive behavior of the waste in these tanks is indefinite and does not reflect the urgent need for a comprehensive and definitive assessment of the probability of a violent chemical reaction. The study should be extended to other metallic compounds of ferrocyanide that are known or believed to be present in the tanks, so that conclusions can be generalized as to the range of temperature and other properties needed for a rapid chemical reaction with sodium nitrate."

Chemical reaction studies on ferrocyanide waste simulants are being conducted by Westinghouse Hanford Company, FAI, PNL, and Los Alamos National Laboratory (LANL). Westinghouse Hanford Company and PNL have produced flowsheet simulant materials for testing and characterization. FAI is conducting adiabatic calorimetry and propagation tests on these same flowsheet materials and on stoichiometric mixtures of pure sodium nickel ferrocyanide and sodium nitrate/nitrite. The test program at LANL was completed in FY 1993.

\subsubsection{Chemical Reaction Studies at Pacific Northwest Laboratory}

Chemical reaction studies are continuing at PNL using flowsheet simulant materials. Waste studies addressing DNFSB Recommendation 90-7.5 are being conducted to determine (1) the aging effects (hydrolysis and radiolysis) from more than 35 years of storage in the tanks;

(2) the speciation of cyanides found in the actual tank waste; and (3) modeling calculations to predict the moisture retaining capability of ferrocyanide wastes in a typical tank system (this work is reported in Section 3.4.3). 


\section{- Progress During Reporting Period.}

Aging Studies. Additional experiments were conducted during the quarter to determine the effect of temperature on the hydrolysis reaction. Data collected previously showed that about $90 \%$ of the soluble ferrocyanide from In-Farm-1B was hydrolyzed at $90^{\circ} \mathrm{C}$ and a dose rate of $1 \times 10^{5} \mathrm{Rad} / \mathrm{h}$. However, very little hydrolysis occurred at 50 and $70^{\circ} \mathrm{C}$ at the same dose rate. Additional hydrolysis experiments were conducted under irradiation at temperatures of $80^{\circ} \mathrm{C}$ and $100{ }^{\circ} \mathrm{C}$ and $1 \times 10^{5} \mathrm{Rad} / \mathrm{h}$. Data have been collected over a three week period for the experiment at $80^{\circ} \mathrm{C}$ and for the first week of an identical experiment at $100{ }^{\circ} \mathrm{C}$, which is continuing. Figure 3-5 shows the production of ammonia as a function of time at each temperature.

The ammonia production observed at $80^{\circ} \mathrm{C}$ was intermediate between the 70 and $90{ }^{\circ} \mathrm{C}$ results obtained previously. An induction period of about 12 days was observed for ammonia production in the $80^{\circ} \mathrm{C}$ experiment. This is longer than the seven-day period that has been observed in all previous experiments at $90{ }^{\circ} \mathrm{C}$. In the first 12 days of the $80^{\circ} \mathrm{C}$ experiment, the ammonia concentration first increased, then decreased. The decrease is consistent with ammonia destruction occurring at a faster rate than ammonia formation during this period. The induction period appears to be much shorter than seven days in the $100^{\circ} \mathrm{C}$ experiment. Thus, the induction is clearly associated with a thermally-controlled process, rather than a gamma radiationcontrolled process.

From gas analysis data, the $\mathrm{O}_{2}$ concentration increases until rapid ammonia generation starts, behavior that is consistent with previous hydrolysis experiments. In order to investigate the potential role of $\mathrm{O}_{2}$ in the induction period, two vessels were introduced into the gamma field at $1 \times 10^{5} \mathrm{Rad} / \mathrm{h}$ with contents identical to the $80{ }^{\circ} \mathrm{C}$ experiment except that the cover gas contained $20 \% \mathrm{O}_{2} / 80 \% \mathrm{Ar}$ rather than the usual $100 \%$ Ar. As shown in Figure 3-6, the results are identical over the first five days whether $\mathrm{O}_{2}$ is present or not. Oxygen apparently plays no role in the process associated with the induction period and the induction period is apparently not affected by a requirement that a certain $\mathrm{O}_{2}$ concentration to be attained before more rapid hydrolysis can occur. The influence of $\mathrm{O}_{2}$ on later stages of the hydrolysis has not been investigated.

Cyanide Speciation. It is desirable to reduce the ${ }^{137} \mathrm{Cs}$ content in actual ferrocyanide tank samples prior to analysis for ferrocyanide species in order to reduce personnel exposure to radiation levels as low as reasonably achievable (ALARA). This would allow samples to be removed from the hot cell environment for bench-top handling during speciation analysis.

The cesium content of small batches of In-Farm-2 flowsheet simulant samples were increased by a factor of 30 . The samples were centrifuged at $2000 \mathrm{rpm}$ for approximately one hour. After centrifugation the samples were dried at $50^{\circ} \mathrm{C}$ in air 


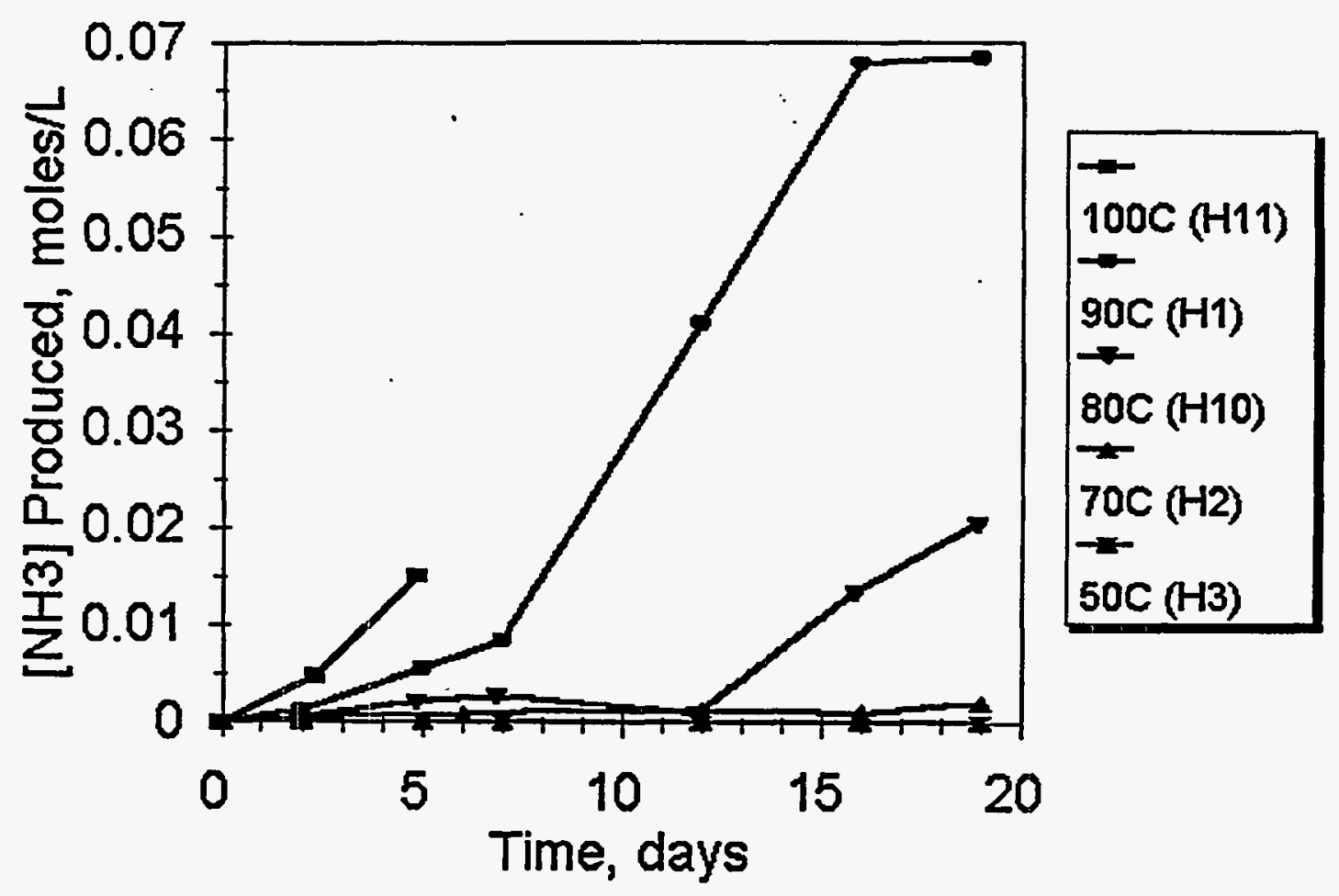

Figure 3-5. Production of Ammonia During Hydrolysis of In-Farm-1B in a Gamma Field as a Function of Temperature.

for several days. Approximately one gram of each simulant was dissolved in 10.0 to $20.0 \mathrm{ml}$ of ethylenediaminetetraacetic acid/ethylenediamine (EDTA/en) elixir ${ }^{1}$ and passed through a plastic column containing 5 grams of ion exchange resin. The ion exchange resin used was AG 50W-X82, 50-100 mesh. The resin was converted to the sodium form by adding excess sodium hydroxide and rinsing with distilled water until the eluent $\mathrm{pH}$ was neutral. Before passing the spiked simulant samples through the ion exchange column, $15 \mathrm{~mL}$ of the EDTA/en elixir solution was passed through the column. A $5.0 \mathrm{~mL}$ sample of the dissolved simulated waste was pipetted onto the column and allowed to elute using gravity flow. Additional EDTA/en elixir was added to the column to ensure complete transfer of sample through the column. All eluent fractions were retained and combined.

${ }^{1} \mathrm{EDTA} / \mathrm{en}$ solution $=5 \mathrm{~g}$ EDTA $+5 \mathrm{~g}$ ethylenediamine diluted to $100 \mathrm{ml}$ with water.

${ }^{2}$ A product of BioRad Company, Redmond, California. 


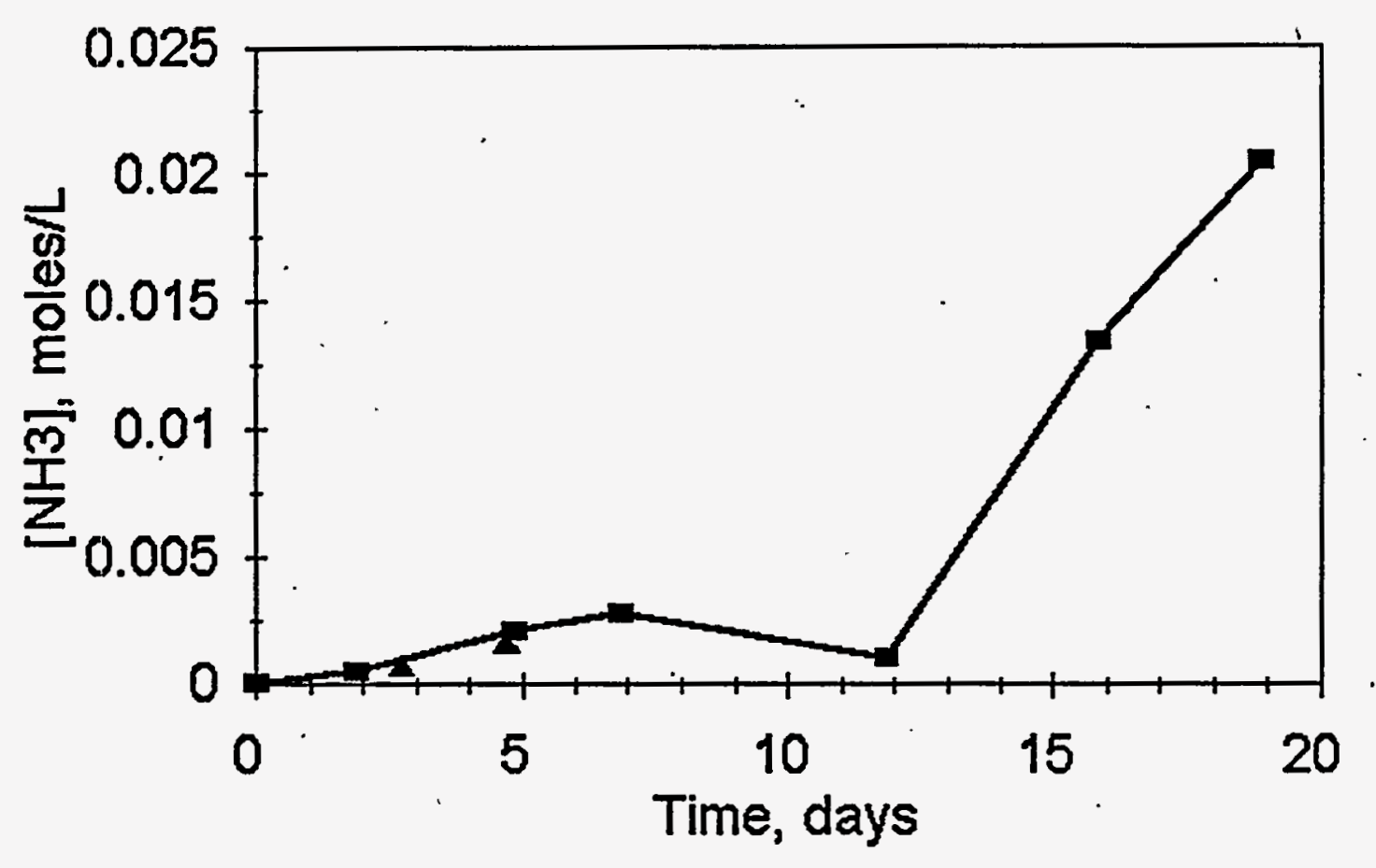

\section{- no 02 * with $\mathrm{O} 2$}

Figure 3-6. Production of Ammonia During the Hydrolysis of In-Farm-1B in a Gamma Field at $80^{\circ} \mathrm{C}$ in the Presence or Absence of Oxygen.

the sodium form by adding excess sodium hydroxide and rinsing with distilled water until the eluent $\mathrm{pH}$ was neutral. Before passing the spiked simulant samples through the ion exchange column, $15 \mathrm{~mL}$ of the EDTA/en elixir solution was passed through the column. A $5.0 \mathrm{~mL}$ sample of the dissolved simulated waste was pipetted onto the column and allowed to elute using gravity flow. Additional EDTA/en elixir was added to the column to ensure complete transfer of sample through the column. All eluent fractions were retained and combined.

The cyanide content of the In-Farm-2 samples was measured before and after ion exchange by FTIR spectroscopy techniques. Cesium concentrations were measured by atomic absorption spectroscopy. The ion exchange technique successfully removed (86\%) of the cesium while maintaining a $98.2 \%$ recovery of ferrocyanide.

- Planned Work For Subsequent Months. Aging experiments will be continued using In-Farm flowsheet simulant. Knowledge of factors that impact the free cyanide concentration in solution are important to understanding the mechanism(s) involved in 
the hydrolysis reactions. Experiments will be conducted to determine factors that may have influenced hydrolysis rates under actual tank waste conditions.

Cyanide speciation studies, using ion chromatography (IC) methods and solution IR methods, will continue until the validated techniques and procedures can be routinely applied to samples in analytical laboratories at PNL and Westinghouse Hanford Company. The studies will include determination of interferences and possible corrections.

- Problem Areas and Actions Taken. All laboratory work was halted within - radioactive control areas in the 325 Building April 1994. Restart plans for the building were approved by DOE in December 1994, and restart of work on an individual task and laboratory basis has started. The cyanide speciation and cesium uptake tasks are anticipated to resume in the near future.

\section{- Milestone Status.}

- July 31, 1995 (Est). PNL issues a report, cleared for public release, on solution IR and IC cyanoferrate speciation activities and application for routine measurements in the analytical laboratories. The report will be issued 180 days from approval for the restart of this radiological activity in the 325 Building.

- July 31, 1995 (Est). PNL issues a report, cleared for public release, on cesium uptake capacity of ferrocyanide. The report will be issued 180 days from approval for the restart of this radiological activity in the 325 Building.

- September 29, 1995. PNL issues the final report integrating all Ferrocyanide Safety Program hydrolysis and radiolysis aging activities.

\subsubsection{Preparation and Characterization of Ferrocyanide Simulants}

Pure sodium nickel ferrocyanide is being prepared and analyzed to determine its chemical reaction properties with stoichiometric mixtures of sodium nitrate/nitrite as a function of water content. These tests are being conducted by FAI to clearly define the margin of safety between the theoretical and experimental propagation limits for ferrocyanide. These tests are run in the FAI Reactive Systems Screening Tool (RSST). These tests and previous tests with simulants that represent ferrocyanide waste stored in SSTs, along with analyses of actual tank waste samples, waste tank monitoring, and waste modeling, provide information to characterize with a great deal of assurance safety concerns relating to the sludge in each of the ferrocyanide tanks.

- Progress During Reporting Period. A procedure was developed and a test batch prepared to produce pure disodium mononickel ferrocyanide. A large yield factor was obtained with the modified procedure. X-ray diffraction analysis of this material 
indicates that it is a single phase and that the structure was a face-centered cubic unit cell with an "a" lattice parameter of $10.299 \pm 0.004$ Angstroms. These characteristics are expected for ferrocyanide structures in general. The waters of hydration were determined to be a whole value of 3.0 , which implies that the material is a single phase. Inductively Coupled Plasma, X-ray fluorescence, and FTIR analyses are now in progress. If these analyses support the conclusion that this test material is pure disodium mononickel ferrocyanide, then a large test batch will prepared by this procedure for propagation testing at FAI.

FAI is developing a general Contact-Temperature Ignition (CTI) criterion for ferrocyanide and organic waste (Fauske 1994). The CTI condition, which accounts for moisture, implies that the contact temperature or interface temperature between reacted and unreacted materials must exceed the ignition temperature in order to support sustained combustion. Recent tube propagation tests including both synthetic ferrocyanide and surrogate organic substances confirm the CTI criterion.

Application of the CTI condition to ferrocyanide leads to a lower bound theoretical fuel concentration value in case of low moisture of $10 \mathrm{wt} \% \mathrm{Na}_{2} \mathrm{NiFe}(\mathrm{CN})_{6}$ that would assure the absence of condensed-phase propagating reactions at ambient waste temperature, as compared to the $8 \mathrm{wt} \%$ value used in the resolution of the Ferrocyanide USQ (Postma et al. 1994). As such, only tanks 241-C-108 and -C-111 are left in the Conditionally Safe category and all other ferrocyanide tanks fall into the Safe category (see Table 7-1 of Postma et al. 1994). The two C Farm tanks may well fall into the Safe category after waste from these tanks are analyzed.

- Planned Work for Subsequent Months. FAI will conduct propagation geometry tests using stoichiometric mixtures of sodium nickel ferrocyanide and sodium nitrate/nitrite with varying amounts of water to determine the effects of upward propagation, larger diameter samples $(50 \mathrm{~mm})$, and initial starting temperatures on the onset temperature for propagation.

The theoretical derivation of the CTI criterion presented in Fauske (1994) is being expanded and will be provided in more detail in a future report. Additional tests with organic surrogates and ferrocyanide simulants will also be conducted. This work is expected to result in one set of criteria that can be applied to both organic and ferrocyanide tanks to define the upper composition fuel limit for safe storage of the waste in the tanks.

- Milestone Status.

- July 31, 1995. Westinghouse Hanford Company releases a report, approved for public release, documenting the development and confirmation by testing of the CTI criterion model. 
- September 30, 1995. Westinghouse Hanford Company completes the ferrocyanide calorimetry and propagation test program at FAI as specified by Westinghouse Hanford Company, and prepares reports, available for public release, that support final resolution of the Ferrocyanide Safety Issue.

\subsection{EMERGENCY RESPONSE PLANNING}

"The Board had recommended 'that an action plan be developed for the measures to be taken to neutralize the conditions that may be signaled by alarms.' Two types of measures are implied: actions to respond to unexpected degradation of a tank or its contents, and actions to be taken if an explosion were to occur. Your implementation plan stated that 'the current contingency plans ... will be reviewed and revised if needed.' We do not consider that this proposed implementation of the Board's recommendation is adequately responsive. It is recommended that a written action plan founded on demonstrated principles be prepared as soon as possible, that would respond to indications of onset of abnormal temperatures or other unusual conditions in a ferrocyanide-bearing tank, to counter any perceived growth in hazard. A separate emergency plan should be formulated and instituted, covering measures that would be taken in event of an explosion or other event leading to an airborne release of radioactive material from the tanks, and that would protect personnel both on and off the Hanford Site. The Board believes that even though it is considered that the probability is small that such an event will occur, prudence dictates that steps be taken at this time to prepare the means to mitigate the unacceptable results that could ensue."

The original Action Plan for Response to Abnormal Conditions in Hanford Radioactive Waste Tanks Containing Ferrocyanide (Cash and Thurman 1991) was prepared in response to DNFSB Recommendation 90-7.6. The plan describes the steps to be taken if a temperature increase trend above the tank temperature baseline is measured in any of the ferrocyanide tanks. The document was revised to include the monitoring criteria and responses for abnormal levels of flammable and toxic gases, as well as the reporting requirements, if established criteria are exceeded. The second revision of the plan was released in June 1994 (Fowler 1994).

The Tank Farm Stabilization Plan For Emergency Response (WHC 1991) was issued in March 1991. If a radioactive release from a ferrocyanide tank were to occur, it would be detected by one or more radiation monitoring systems. Significant airborne or ground surface releases that spread beyond the immediate tank or tank farm would be detected by the tank farm area radiation detectors. These monitoring systems are on all tank farms. An emergency involving an underground radioactive waste storage tank is a unique event with potentially serious consequences both onsite and offsite. The Stabilization Plan provides quick, preplanned actions that can be used to stabilize an emergency event at an underground radioactive waste storage tank.

All actions with respect to emergency planning, emergency event recognition, protective action recommendations, and emergency response procedures have been completed. Further 
revisions and occasional validation exercises will be accomplished as part of the normal Westinghouse Hanford Company and DOE emergency planning efforts. No further reporting on these issues is planned, and this part of DNFSB Recommendation 90-7.6 is considered complete and closed.

DOE considers this recommendation to be closed with the proviso that the abnormal conditions response plan and emergency plans are (1) reviewed on a periodic basis; (2) revised and updated as required to incorporate any additional controls determined appropriate by the ongoing Waste Tank Safety Program investigations [e.g., the Action Plan for Response to Abnormal Conditions in Hanford Site Radioactive Waste Tanks Containing Ferrocyanide was updated and released in June 1994 (Fowler 1994)]; and (3) validation exercises for various waste tank accident scenarios are conducted periodically (exercises for the tank farms are conducted every two years).

- Progress During Reporting Period. As noted in previous reports, all of the planned milestones for this task were completed.

- Planned Work For Subsequent Months. None planned.

- Problem Areas and Action Taken. None.

- Milestone Status. All milestones have been completed. 
WHC-EP-0474-15

This page intentionally left blank. 


\subsection{IMPLEMENTATION OF THE WYDEN AMENDMENT}

The Wyden Amendment (Public Law 101-510, Section 3137, 1990) requires that:

"...the Secretary of Energy shall. identify. which single-shelled or double-shelled high-level nuclear waste tanks at the Hanford Nuclear Reservation, Richland, Washington, may have a serious potential for release of high-level waste due to uncontrolled increases of temperature or pressure. After completing such identification, the Secretary shall determine whether continuous monitoring is being carried out to detect a release or excessive temperature or pressure at each tank so identified. If such monitoring is not being carried out, as soon is practicable the Secretary shall install such monitoring, but only if a type of monitoring that does not itself increase the danger of a release can be installed."

\subsection{THE WATCH LIST}

In March 1989, using process knowledge, process records, transfer records, and log books, Westinghouse Hanford Company (Nguyen 1989) identified 22 Hanford Site tanks as potentially containing $1,000 \mathrm{~g}$-moles [211 $\mathrm{kg}(465 \mathrm{lb})]$ or more of ferrocyanide [as the $\mathrm{Fe}(\mathrm{CN})_{6}^{4}$ anion]. To avert possible injury to personnel and damage to the facility or environment, strict controls were identified for these and other Safety Issue tanks. These controls were described in the document, Operating Specifications for Watch List Tanks (WHC 1990). Tanks identified via this document [see WHC (1994) for latest revision] have been commonly referred to as Watch List tanks. Two additional ferrocyanide tanks were identified in January 1991 (Borsheim and Cash 1991), increasing the number of ferrocyanide tanks to 24.

In November 1990, the Wyden Amendment (Public Law 101-510, Section 3137, 1990) was enacted. This law required the identification of Hanford Site tanks that may have a serious potential for release of high-level waste. In February 1991 (Harmon 1991), the 24 ferrocyanide tanks were among the tanks identified, and were included in the subsequent July 1991 report to Congress (Watkins 1991) that responded to the Wyden Amendment. However, re-examination of the historical records (Borsheim and Simpson 1991) indicated that six of the 24 tanks did not contain the requisite $1,000 \mathrm{~g}$-moles of ferrocyanide. Therefore, these six tanks should not have been included on the Watch List nor been identified in the response to the Wyden Amendment. The six tanks were subsequently removed from the Watch List (Anttonen 1993, Sheridan 1994b) (Note: these tanks do not contain greater than $8 \mathrm{wt} \% \mathrm{Na}_{2} \mathrm{NiFe}(\mathrm{CN})_{6}$ and should not be on the Watch List for this reason also).

As part of the overall safety screening module being conducted by TWRS, all of the Hanford Site SSTs will be core sampled and characterized [note: the $115 \mathrm{cal} / \mathrm{g}$ fuel criterion established for ferrocyanide tanks is now the adopted limit used for safety screening (Babad 
and Redus 1994)]. Eighteen ferrocyanide tanks are currently on the Watch List, and no more tanks are expected to be added to the Ferrocyanide Watch List.

Work conducted since 1991 on ferrocyanide reactions has resulted in a change of the criterion used for placing ferrocyanide tanks on the Watch List. The $1,000 \mathrm{~g}$-mole inventory criterion has now been replaced with a fuel concentration criterion of $115 \mathrm{cal} / \mathrm{g}$ of dry sample (this is an energy equivalent to a concentration of $8 \mathrm{wt} \% \mathrm{Na}_{2} \mathrm{NiFe}(\mathrm{CN})_{6}$ in the waste). The fuel concentration criterion more accurately reflects the risk associated with ferrocyanide tanks. Ferrocyanide tanks with concentrations less than an energy equivalent of $8 \mathrm{wt} \%$ $\mathrm{Na}_{2} \mathrm{NiFe}(\mathrm{CN})_{6}$ cannot support a propagating reaction, and are categorized as safe. Detailed rationale for the $115 \mathrm{cal} / \mathrm{g}$ fuel concentration criterion is presented in Postma et al. (1994a).

Core sampling and characterization efforts will determine the ferrocyanide concentration for those tanks that bound aging (see Sections 2.2 and 3.4). After adequate characterization, if these tanks contain concentrations less than $8 \mathrm{wt} \% \mathrm{Na}_{2} \mathrm{NiFe}(\mathrm{CN})_{6}$ (i.e., the fuel value of the maximum concentration is less than $115 \mathrm{cal} / \mathrm{g}$ ), then a request will be made by Westinghouse Hanford Company for DOE concurrence to remove all of the ferrocyanide tanks from the Watch List.

Some sample bias and analytical error is unavoidable; therefore, confidence intervals have been established to specify when it is appropriate to conclude that a ferrocyanide tank contains concentrations less than an energy equivalent of $8 \mathrm{wt} \% \mathrm{Na}_{2} \mathrm{NiFe}(\mathrm{CN})_{6}$. An $80 \%$ confidence interval was chosen for tanks with a fuel concentration of $8 \mathrm{wt} \% \mathrm{Na}_{2} \mathrm{NiFe}(\mathrm{CN})_{6}$. That is, if five ferrocyanide tanks contain exactly an energy equivalent of $8 \mathrm{wt} \%$ $\mathrm{Na}_{2} \mathrm{NiFe}(\mathrm{CN})_{6}$, statistically, four tanks would remain on the Watch List and one tank would be removed. The possibility of removing a ferrocyanide tank from the Watch List decreases substantially as the fuel concentration increases. The confidence intervals increase to 95 and $99 \%$ at $\mathrm{Na}_{2} \mathrm{NiFe}(\mathrm{CN})_{6}$ concentrations of 12 and 15 wt\%, respectively. Detailed discussions on how sample bias and analytical error are factored into determining the actual fuel concentrations in a ferrocyanide tank are given in the Ferrocyanide Data Quality Objectives document (Meacham et al. 1994a).

- Planned Work To Complete Program. An increased understanding of ferrocyanide aging indicates that little ferrocyanide remains, and the assumption that it is necessary to core sample all ferrocyanide tanks may not be valid. By characterizing the waste in only those tanks that bound aging (i.e., tanks with conditions least conducive to aging), the Ferrocyanide Safety Issue could be resolved much earlier and at a substantially reduced cost. As more core sample data become available, the need to sample all the ferrocyanide tanks will be reexamined.

- Milestones.

- January 31, 1996. Westinghouse Hanford Company issues documentation supporting resolution of the Ferrocyanide Safety Issue for the four C Farm tanks, and recommends resolution of the Ferrocyanide Safety Issue for C Farm tanks. 
- July 31, 1996. Westinghouse Hanford Company receives DOE approval to resolve the Ferrocyanide Safety Issue for C Farm tanks.

- March 31, 1997. Westinghouse Hanford Company prepares documentation to support resolution of the Ferrocyanide Safety Issue for the remaining 14 tanks, and recommends Ferrocyanide Safety Issue resolution for all remaining tanks.

- September 30, 1997. Westinghouse Hanford Company receives DOE approval to resolve the Ferrocyanide Safety Issue. This completes the Ferrocyanide Safety Program.

\subsection{TEMPERATURE MONITORING}

The installation of temperature monitoring capabilities is discussed in Sections 3.1.2.1 and 3.2.2. Installation of instrument trees and continuous temperature monitoring are considered prudent waste management practices (monitoring temperatures helps follow the initiators' side of the fire triangle). Therefore, new instrument trees will be installed in ferrocyanide tanks, even though the ferrocyanide waste has aged and little fuel value remains.

- Planned Work To Complete Program. Instrument trees will be inserted in the remaining ferrocyanide tanks (currently there are six ferrocyanide tanks that still require installation of trees). This will provide two operating instrument trees in all but three ferrocyanide tanks (see Section 3.1.2.1 for discussion on instrument trees). All instrument trees will be connected to TMACS for continuous monitoring. Completion of this task is anticipated by the end of FY 1995.

\section{- Milestones}

- September 30, 1995. Westinghouse Hanford Company completes installation of instrument trees in all ferrocyanide tanks and connects trees to TMACS. Existing temperature sensing elements in tanks 241-BY-105 and -106 will be replaced, if necessary.

\subsection{PRESSURE MONITORING}

The ferrocyanide tanks were initially identified as having "a serious potential for release" and were placed on the Watch List because insufficient data were available on the probability for ferrocyanide-nitrate/nitrite reactions. Pressure monitoring is not presently installed on the ferrocyanide tanks. It would take several years to install pressure monitoring instrumentation because of the capital project time cycle. Ferrocyanide waste has probably degraded (aged) significantly, and all of the tanks may now contain less than the $8 \mathrm{wt} \% \mathrm{Na}_{2} \mathrm{NiFe}(\mathrm{CN})_{6}$ fuel concentration specified for the safe category (see also Postma et al. 1994a). This eliminates the need for continuous pressure monitoring for offgases from a ferrocyanide reaction. 
The rationale for not installing pressure monitors in ferrocyanide tanks was prepared and submitted to DOE in July 1994 (Payne 1994b). Low gas generation rates (Fowler and Graves 1994) and the low potential for exothermic ferrocyanide reactions (Postma et al. 1994a) indicated that continuous pressure monitoring is not warranted.

- Planned Work For Subsequent Months. No additional work is planned in this area since DOE has concurred that pressure monitoring is not required (O'Leary 1994).

- Milestones. None. 


\subsection{PROGRAM SCHEDULES AND MILESTONES}

Schedules (Figure 5-1) are presented in this section. The schedules review milestones for FY 1994 through the expected end of the program in FY 1997. The sequence and anticipated completion dates of the major milestones leading to resolution of the Ferrocyanide Safety Issue are presented. Closure of DNFSB recommendations are indicated on the schedule as diamonds, and completion of interim milestones are indicated as triangles. The schedules are statused through December 31, 1994. 
Figure 5-1. Ferrocyanide Waste Tank Safety Schedule. (Sheet 1 of 2)

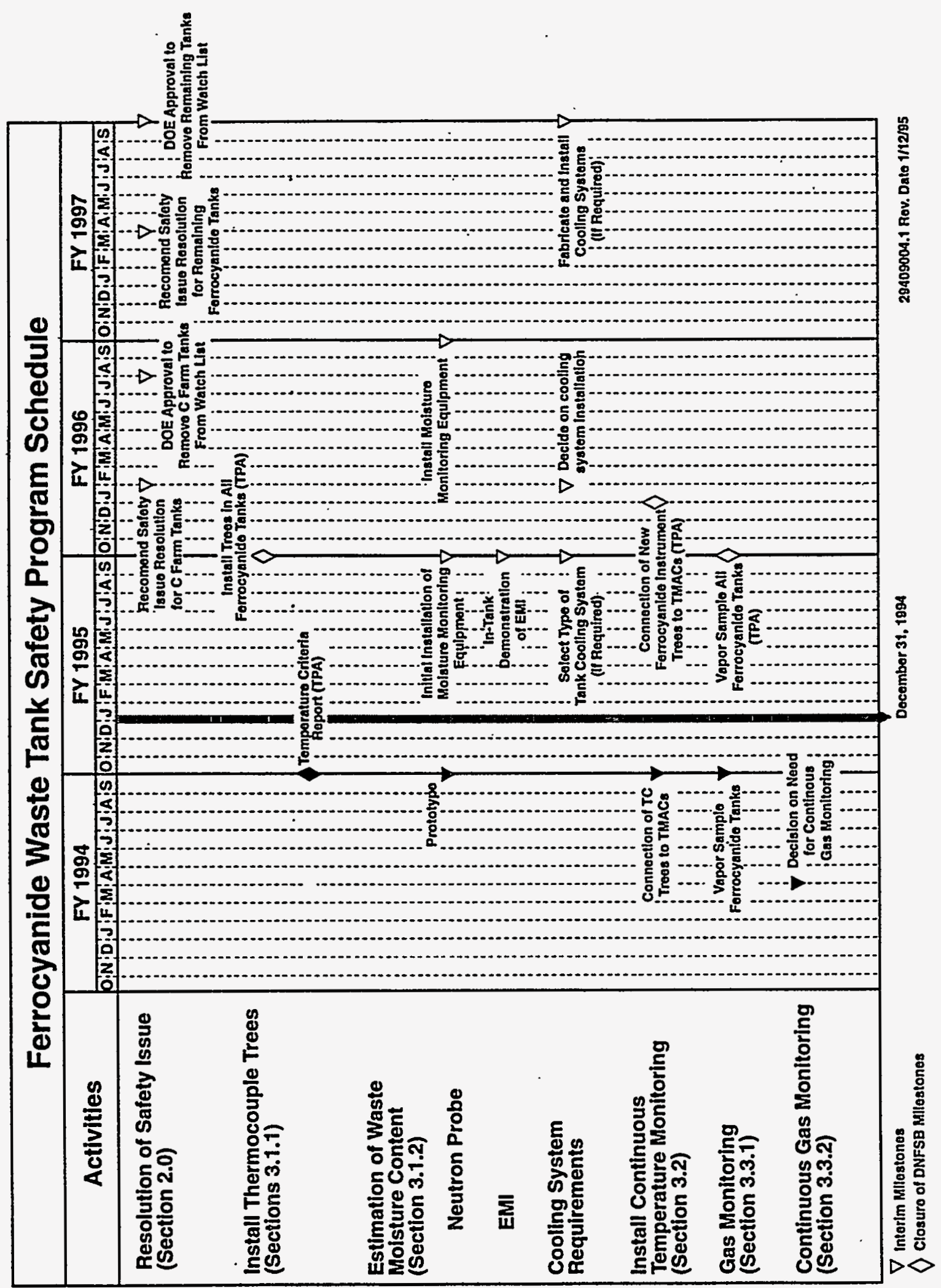


Figure 5-1. Ferrocyanide Waste Tank Safety Schedule. (Sheet 2 of 2)

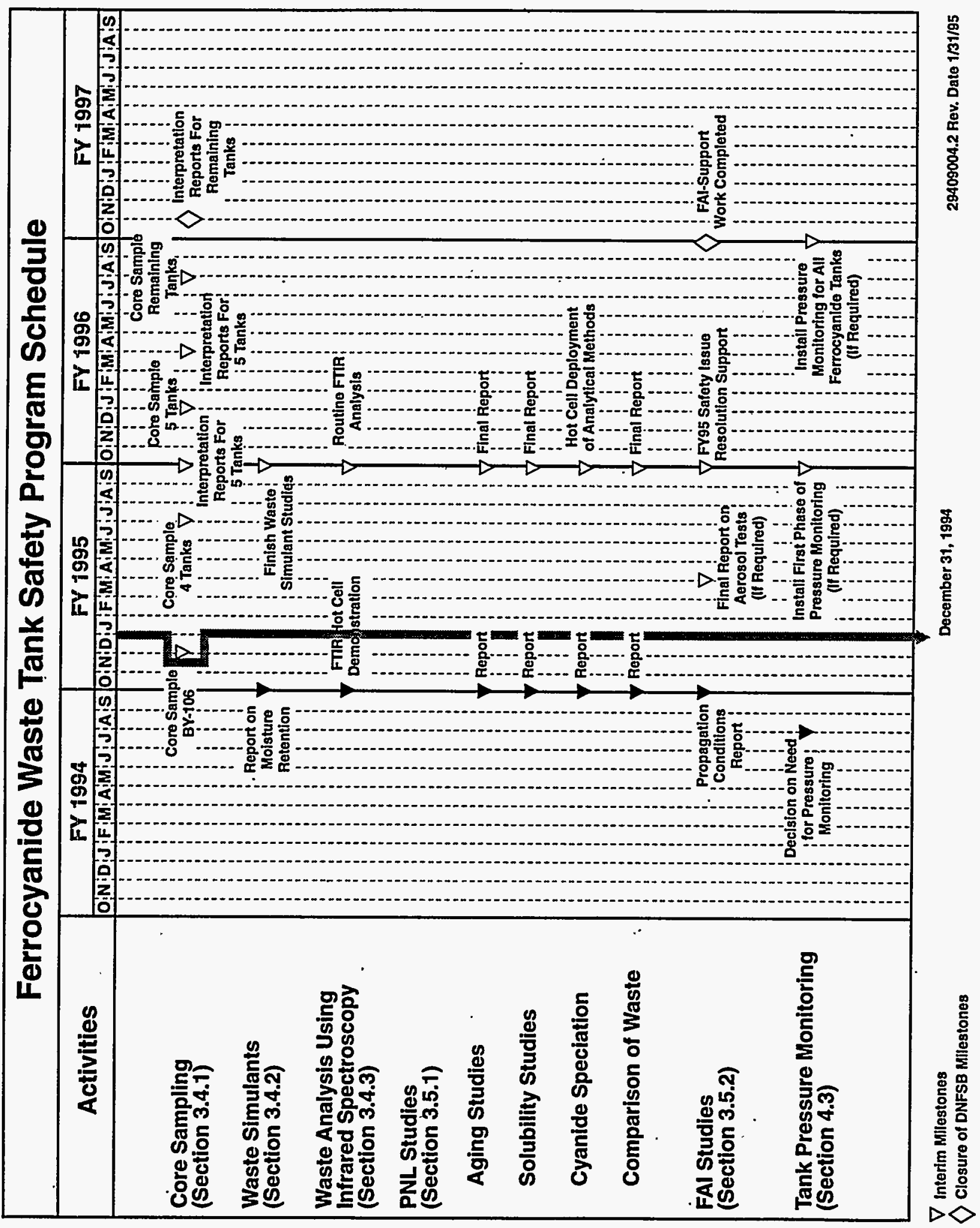


This page intentionally left blank. 


\subsection{REFERENCES}

Alumkal, W. T., 1993, Ferrocyanide Safety Program: Request for Removal of Two Tanks from the Safety Watch List, (letter 9304645B.R2 to J. H. Anttonen, DOE-RL, September 20), Westinghouse Hanford Company, Richland, Washington.

Anttonen; J. H., 1993, Resolution of Unreviewed Safety Question (USQ) for Four Ferrocyanide Tanks, (letter 9304645B/93-CAB-223 to T. M. Anderson, President, Westinghouse Hanford Company, July 9), U.S. Department of Energy, Richland Operations Office, Richland, Washington.

Babad, H., and K. S. Redus, 1994, Tank Safety Screening Data Quality Objective, WHC-SD-WM-SP-004, Rev. 0, Westinghouse Hanford Company, Richland, Washington.

Borsheim, G. L., and R. J. Cash, 1991, Unusual Occurrence - Addition of Two Tanks to List of Unreviewed Safety Question Tanks Containing Ferrocyanide, WHC-91-0096-TFARM, Final, dated February 13, Westinghouse Hanford Company, Richland, Washington.

Borsheim, G. L., and B. C. Simpson, 1991, An Assessment of the Inventories of Ferrocyanide Watch List Tanks, WHC-SD-WM-EP-133, Rev. 0, Westinghouse Hanförd Company, Richland, Washington.

Borsheim, G. L., J. E. Meacham, R. J. Cash, and B. C. Simpson, 1993, Ferrocyanide Safety Program: Rationale for Removing Six Tanks From the Safety Watch List, WHC-MR-0429, Westinghouse Hanford Company, Richland, Washington.

Bussell, J. H., 1992, Engineering Evaluation of Thermocouples in Ferrocyanide Watch List Tanks, WHC-SD-WM-ER-134, Rev. 0 and Rev. 0A, Westinghouse Hanford Company, Richland, Washington.

Cady, H. H., 1993, Evaluation of Ferrocyanide/Nitrate Explosive Hazard, LA-12589-MS, Los Alamos National Laboratory, Los Alamos, New Mexico.

Cash, R. J., 1991, Implementation Plan for the Defense Nuclear Facilities Safety Board Recommendation 90-7, WHC-EP-0415, Rev. 0, Westinghouse Hanford Company, Richland, Washington.

Cash, R. J., and J. Thurman, 1991, Action Plan for Response to Abnormal Conditions in Hanford Site Radioactive Waste Tanks Containing Ferrocyanide, EP-0407, Rev. 0, Westinghouse Hanford Company, Richland, Washington. 
Claybrook, S. W., and S. A. Wood, 1994, Organic Evaporation in Waste Tank C-103, WHC-SD-WM-ER-344, Rev. 0, Westinghouse Hanford Company, Richland, Washington.

Crowe, R. D., M. Kummerer, and A. K. Postma, 1993, Estimation of Heat Load in Waste Tanks Using Average Vapor Space Temperatures, WHC-EP-0709, Westinghouse Hanford Company, Richland, Washington.

Deaton, D. E., 1990, Unusual Occurrence - Unreviewed Safety Questions Regarding Tanks Containing Ferrocyanide, WHC-90-B003-R1 (Update 10-22-90), Westinghouse Hanford Company, Richland, Washington.

Dickinson, D. R., J. M. McLaren, G. L. Borsheim, and M. D. Crippen, 1993, Ferrocyanide - Safety Program: Credibility of Drying Out Ferrocyanide Tank Waste by Hot Spots, WHC-EP-0648, Rev. 0, Westinghouse Hanford Company, Richland, Washington.

DOE, 1987, Final Environmental Impact Statement, Disposal of Hanford Defense High-Level, Transuranic and Tank Waste, Hanford Site, Richland, Washington, DOE/EIS-0113, Vol. 1 through 5, U.S. Department of Energy, Washington, D.C.

DOE, 1994a, Recommendation 93-5 Implementation Plan, DOE/RL 94-0001, U.S. Department of Energy, Richland Operations Office, Richland, Washington.

DOE, 1994b, Program Plan for Resolution of the Ferrocyanide Waste Tank Safety Issue at the Hanford Site, DOE/RL-94-110, U.S. Department of Energy, Richland Operations Office, Richland, Washington.

Epstein, M., H. K. Fauske, M. D. Crippen, D. R. Dickinson, J. D. McCormack, R. J. Cash, J. E. Meacham, and C. S. Simmons, 1994, Ferrocyanide Safety Program: An Assessment of the Possibility of Ferrocyanide Sludge Dryout, WHC-EP-0816, Westinghouse Hanford Company, Richland, Washington.

Fauske, H. K., 1994, The Contact-Temperature Ignition (CTI) Criterion for Propagating Chemical Reactions and Application to Hanford Waste, FAI/94-103, Fauske and Associates, Inc., Burr Ridge, Illinois.

Fischer, G., and M. Bader, 1994, "Melt Film Technique for IR Spectroscopy," American Laboratory, pp. 32c-32h, November 1994.

FR, 1990, "Implementation Plan for Recommendation 90-3 at the Department of Energy's Hanford Site, Washington," Federal Register, Defense Nuclear Facilities Safety Board Recommendation 90-7, Vol. 55, No. 202, pp. 42243 - 42244. 
Fowler, K. D., 1994, Action Plan for Response to Abnormal Conditions in Hanford Site Radioactive Waste Tanks Containing Ferrocyanide, WHC-EP-0407, Rev. 2, Westinghouse Hanford Company, Richland, Washington.

Fowler, K. D., and R. D. Graves, 1994, Decision Analysis for Continuous Cover Gas Monitoring of Ferrocyanide Watch List Tanks, WHC-EP-0743, Westinghouse Hanford Company, Richland, Washington.

Gerton, R. E., 1994, Environmental Assessment (EA) and Finding of No Significant Impact (FONSI) for the Waste Tank Safety Program at the Hanford Site, (DOE/EA-0915), (letter 9402034B/94-SST-053 to President, Westinghouse Hanford Company, March 8), U.S. Department of Energy, Richland, Washington.

Grigsby, J. M., D. B. Bechtold, G. L. Borsheim, M. D. Crippen, D. R. Dickinson, G. L. Fox, D. W. Jeppson, M. Kummerer, J. M. McLaren, J. D. McCormack, A. Padilla, B. C. Simpson, and D. D. Stepnewski, 1992, Ferrocyanide Waste Tank Hazard Assessment-Interim Report, WHC-SD-WM-RPT-032, Rev. 1, Westinghouse Hanford Company, Richland, Washington.

Harmon, H. D., 1991, Safety Measures for Waste Tanks at Hanford Site, Richland, Washington, (letter 9059124.1 to R. E. Gerton, DOE-RL, February 8), Westinghouse Hanford Company, Richland, Washington.

Hertelendy, N. A., 1993, Final Test Report - Ultra High Pressure Water as a Tool to Bore, Drill, Cut or Penetrate Hard Saltcake-Like Nuclear Waste, WHC-SD-WM-RPT-132, Rev. 0, Westinghouse Hanford Company, Richland, Washington.

King, C. V., 1994, Ferrocyanide Safety Program: Results of Relative Humidity Experiments Using Ferrocyanide Waste Simulants, WHC-SD-WM-TRP-215, Rev. 0, Westinghouse Hanford Company, Richland, Washington.

Kress, T., K. Bandyopadhyay, P. d'Entremont, S. Slezak, and M. Reich, 1990, Risk of a Ferrocyanide Explosion in the Hanford Waste Tank Farm, (memorandum to John Tseng, DOE-HQ, September 20), Ad Hoc Task Force formed by U.S. Department of Energy to evaluate the ferrocyanide safety concerns at the Hanford Site.

McLaren, J. M., 1993, Ferrocyanide Safety Program: Updated Thermal Analysis Model for Ferrocyanide Tanks with Application to Tank 241-BY-104, WHC-EP-0669, Westinghouse Hanford Company, Richland Washington.

McLaren, J. M., 1994a, Ferrocyanide Safety Program: Thermal Analysis of Ferrocyanide Tanks, Group I, WHC-EP-0729, Westinghouse Hanford Company, Richland, Washington. 
McLaren, J. M. 1994b, Ferrocyanide Safety Program: Thermal Analysis of Ferrocyanide Watchlist Tanks, Group II, WHC-EP-0794, Westinghouse Hanford Company, Richland, Washington.

Meacham, J. E., H. Babad, and H. Toffer, 1993, Moisture Monitoring of Ferrocyanide Tanks: An Evaluation of Methods and Tools, WHC-EP-0658, Westinghouse Hanford Company, Richland, Washington.

Meacham, J. E., R. J. Cash, G. T. Dukelow, J. W. Buck, C. M. Anderson, B. A. Pulsipher, J. J. Toth, and P. J. Turner, 1994a, Data Requirements for the Ferrocyanide Safety Issue Developed Through the Data Quality Objectives Process, WHC-SD-WM-DQO-007, Rev. 0, Westinghouse Hanford Company, Richland, Washington.

Meacham, J. E., R. J. Cash, and G. T. Dukelow, 1994b, Quarterly Report on the Ferrocyanide Safety Program for the Period Ending June 30, 1994, WHC-EP-0474-13, Westinghouse Hanford Company, Richland, Washington.

Nguyen, D. M., 1989, Data Analysis of Conditions in Single-Shell Tanks Suspected of Containing Ferrocyanide, (internal memo 13314-89-025 to N. W. Kirch, March 2), Westinghouse Hanford Company, Richland, Washington.

O'Leary, H. R., 1994, [Transmittal of "Program. Plan for Evaluation of the Ferrocyanide Waste Tank Safety issue at the Hanford Site, "DOE/RL-94-110], (letter to J. T. Conway, Chairman, Defense Nuclear Facilities Safety Board, December 2), U.S. Department of Energy, Washington, D.C.

Payne, M. A., 1994a, Ferrocyanide Safety Program: Transmittal of General Accounting Office Closeout Report, (letter 9454280 to R. E. Gerton, DOE-RL, June 16), Westinghouse Hanford Company, Richland, Washington.

Payne, M. A., 1994b, Ferrocyanide Safety Program: Continuous Pressure Monitoring in Ferrocyanide Watch List Tanks, (letter 9455175 to R. E. Gerton, DOE-RL, July 29), Westinghouse Hanford Company, Richland, Washington.

Peach, J. D., 1990, Consequences of Explosion of Hanford's Single-Shell Tanks are Understated, (letter B-241479 to M. Synar, Chairman, Environment; Energy, and Natural Resources Subcommittee, Committee on Government Operations, House of Representatives, October 10), GAO/RCED-91-34, U.S. General Accounting Office, Washington, D.C. 
Postma, A. K., J. E. Meacham, G. S. Barney, G. L. Borsheim, R. J. Cash, M. D. Crippen, D. R. Dickinson, J. M. Grigsby, D. W. Jeppson, M. Kummerer, J. M. McLaren, C. S. Simmons, and B. C. Simpson, 1994a, Ferrocyanide Safety Program: Safety Criteria for Ferrocyanide Watch List Tanks, WHC-EP-0691, Westinghouse Hanford Company, Richland, Washington.

Postma, A. K., D. B. Bechtold, G. L. Borsheim, J. M. Grigsby, R. L. Guthrie, M. Kummerer, M. G. Plys, and D. A. Turner, 1994b, Safety Analysis of Exothermic Reaction Hazards Associated with the Organic Liquid Layer in Tank 241-C-103, WHC-SD-WM-SARR-001, Rev. 0, Westinghouse Hanford Company, Richland, Washington.

Public Law 101-510, Section 3137, 1990, Safety Measures for Waste Tanks at Hanford Nuclear Reservation, U.S. Congress, Washington, D.C. [Also referred to as the Wyden Amendment]

Rebagay, T. V., R. J. Cash, and J. E. Meacham, 1994, Evaluation of FTiR Based Analytical Methods for the Analysis of Simulated Wastes, WHC-SD-WM-TI-664, Rev. 0, Westinghouse Hanford Company, Richland, Washington.

Reffner, J. A., W. T. Wihlborg, and S. W. Strand, 1991, "Chemical Microscopy of Surfaces by Grazing Angle and Internal Reflection FTIR Microscopy," American Laboratory, April 1991.

Relyea, J. F., 1994, The Drying of Sodium Nickel Ferrocyanide at Constant Relative Humidity, (internal memorandum 8H110-JFR-94-054 to D. W. Jeppson, September 23), Westinghouse Hanford Company, Richland, Washington.

Sheridan, T. R., 1994a, Closure of the Ferrocyanide Unreviewed Safety Question, (letter 9401180/94-SST-052 to A. L. Trego, President, Westinghouse Hanford Company, March 4), U.S. Department of Energy, Richland Operations Office, Richland, Washington.

Sheridan, T. R., 1994b, Approval to Remove Two Ferrocyanide Tanks, 241-BX-102 and 241-BX-106, from the "Watch List", (letter 9406684/94-SST-205 to A. L. Trego, President, Westinghouse Hanford Company, November 17), U.S. Department of Energy, Richland Operations Office, Richland; Washington.

Simpson, B. C., G. L. Borsheim, and L. Jensen, 1993a, Tank Characterization Report: Tank 241-C-109, WHC-EP-0688, Westinghouse Hanford Company, Richland, Washington. 
Simpson, B. C., G. L. Borsheim, and L. Jensen, 1993b, Tank Characterization Data Report: Tank 241-C-112, WHC-EP-0640, Rev. 1, Westinghouse Hanford Company, Richland, Washington.

Sloat, R. J., 1954, TBP Plant Nickel Ferrocyanide Scavenging Flowsheet, HW-30399, General Electric Company, Richland, Washington.

Sloat, R. J. 1955, In-Farm Scavenging Operating Procedure and Control Data, HW-38955, General electric Company, Richland, Washington.

Smith, D. A., 1986, Single-Shell Tank Isolation Safety Analysis Report, SD-WM-SAR-006, Rev. 2, Westinghouse Hanford Company, Richland, Washington.

Wagoner, J. D., 1993, Approval of Hanford Site Tank Farm Facilities Interim Safety Basis, (letter 93-TOB-209 to T. M. Anderson, President, Westinghouse Hanford Company, November 18), U.S. Department of Energy, Richland Operations Office, Richland, Washington.

Watkins, J. D., 1991, Report to United States Congress on Waste Tank Safety Issues at the Hanford Site, (letter to D. Quale, President of the Senate, July 16), U.S. Department of Energy, Washington, D.C.

Watson, W. T., 1993, Proof of Principle Report for In-Tank Moisture Monitoring Using an Active Neutron Probe, WHC-EP-0695, Westinghouse Hanford Company, Richland, Washington.

Watson, W. T., S. A. Finfrock, H. Toffer, 1994, Potential Tank Waste Material Anomalies Located Near the Liquid Observation Well: Model Predicted Responses of a Neutron Moisture Detection System, WHC-EP-0809, Westinghouse Hanford Company, Richland, Washington.

WHC, 1990, Operating Specifications for Watch List Tanks, OSD-T-151-00030, Rev. 0, Westinghouse Hanford Company, Richland, Washington.

WHC, 1991, Tank Farm Stabilization Plan for Emergency Response, WHC-SD-PRP-TI-001, Rev. 0, Westinghouse Hanford Company, Richland, Washington.

Wood, S. A., 1992, Gas Space Analysis For Tank C-109, WHC-SD-WM-ER-183, Rev. 0, Westinghouse Hanford Company, Richland, Washington. 
WHC-EP-0474-15

APPENDIX

FERROCYANIDE TANK INFORMATION SUMMARY 
This page intentionally left blank. 
Table A-1. Summary of Contents and Status of Ferrocyanide Tanks

\begin{tabular}{|c|c|c|c|c|c|}
\hline Tank & $\begin{array}{c}\text { Total waste } \\
\text { volume } \\
(1,000 \mathrm{~L})\end{array}$ & $\begin{array}{c}\mathrm{FeCN}^{\mathrm{b}} \\
(1,000 \mathrm{~g} \text {-mole })\end{array}$ & $\begin{array}{l}\text { Heat load } \\
(\mathrm{kW})^{\mathrm{c}}\end{array}$ & $\begin{array}{l}\text { Maximum } \\
\text { temp. } \\
\left({ }^{\circ} \mathrm{C}\right)\left({ }^{\circ} \mathrm{F}\right)\end{array}$ & Status of tanks \\
\hline BY-103 & 1510 & 66 & 1.6 & $\begin{array}{ll}28 & 82\end{array}$ & $\mathrm{NS} ; \mathrm{AL}$ \\
\hline BY-104 & 1540 & 83 & 2.6 & $\begin{array}{ll}53 & 127 \\
45^{\circ} & 113\end{array}$ & IS; Sound \\
\hline BY-105 & 1900 & 36 & 2.6 & $\begin{array}{ll}45 & 113 \\
48 & 119\end{array}$ & NS; AL \\
\hline BY-106 & 2430 & 70 & 3.0 & $\begin{array}{ll}53 & 128\end{array}$ & NS; AL \\
\hline BY-107 & 1010 & 42 & 2.6 & $\begin{array}{cc}37 & 98 \\
-\mathrm{f} & -\end{array}$ & IS; $\mathrm{AL}$ \\
\hline BY-108 & 863 & 58 & 2.7 & $\begin{array}{ll}43 \quad 110 \\
\end{array}$ & $\mathrm{IS} ; \mathrm{AL}$ \\
\hline BY-110 & 1510 & $\overline{71}$ & 2.0 & $\begin{array}{ll}48 & 118 \\
42^{\mathrm{c}} & 108\end{array}$ & IS; Sound \\
\hline BY-111 & 1690 & $\overline{6}$ & 1.6 & $29^{\circ} \quad 84$ & IS; Sound \\
\hline BY-112 & 1100 & 2 & 1.8 & $\begin{array}{ll}33^{e} & 9.1\end{array}$ & IS; Sound \\
\hline C-108 & 250 & 25 & $\overline{1.8}$ & $\begin{array}{ll}25 & 77 \\
27^{\circ} & 80\end{array}$ & IS; Sound \\
\hline C-109 & 250 & $6.8^{2}$ & 2.1 & $\begin{array}{ll}29 & 84 \\
28^{\mathrm{e}} & 82\end{array}$ & IS; Sound \\
\hline$C-111$ & 216 & 33 & 2.0 & $25 \quad 77$ & IS; AL \\
\hline $\mathrm{C}-112$ & 394 & $11.5^{\mathrm{B}}$ & 2.2 & $\begin{array}{ll}29 & 85 \\
30^{\circ} & 86\end{array}$ & IS; Sound \\
\hline$. \mathrm{T}-107$ & 681 & 5 & 0.9 & $\begin{array}{cc}19 & 67 \\
-f & -\end{array}$ & $\mathrm{NS} ; \mathrm{AL}$ \\
\hline
\end{tabular}


Table A-1. Summary of Contents and Status of Ferrocyanide Tanks

\begin{tabular}{|c|c|c|c|c|c|}
\hline Tank & $\begin{array}{l}\text { Total waste } \\
\text { volume } \\
(1,000 \mathrm{~L})\end{array}$ & $\begin{array}{c}\text { FeCN }^{b} \\
(1,000 \text { g-mole })\end{array}$ & $\begin{array}{l}\text { Heat load } \\
\qquad(\mathrm{kW})^{c}\end{array}$ & $\begin{array}{l}\text { Maximum } \\
\text { temp. } \\
\left({ }^{\circ} \mathrm{C}\right)\left({ }^{\circ} \mathrm{F}\right)\end{array}$ & Status of tanks \\
\hline TX-118 & 1310 & $<3$ & 1.4 & $\begin{array}{cc}25 & 77 \\
-f & -\end{array}$ & IS; Sound \\
\hline TY-101 & 447 & 23 & 0.9 & 1967 & IS; AL \\
\hline TY-103 & 613 & 28 & 1.2 & 71 & IS; AL \\
\hline TY-104 & 174 & 12 & 0.9 & $20 \quad 68$ & IS; AL \\
\hline
\end{tabular}

- Reflects removal of four ferrocyanide tanks from Watch List in July 1993 and two additional tanks in October 1994. Tank information and temperature data as of December 1994.

b Inventories from Borsheim and Simpson (1991).

c Heat load values from Table 7-1 in Crowe et al. (1993).

d IS - Interim Stabilized Tank; NS - Not Stabilized; AL - Assumed Leaker Tank; Sound - Non-Leaking Tank.

- Readings from new instrument trees; tank 241-BY-105 already had two trees.

${ }^{f}$ Readings have not yet been taken on this new instrument tree.

8 Calculated as ferrocyanide $\left[\mathrm{Fe}\left(\mathrm{CN}_{6}^{4}\right]\right.$ based on the total cyanide values reported in Simpson et al. (1993a, 1993b). 
Table A-2. Ferrocyanide Tank Vapor Sampling Summary

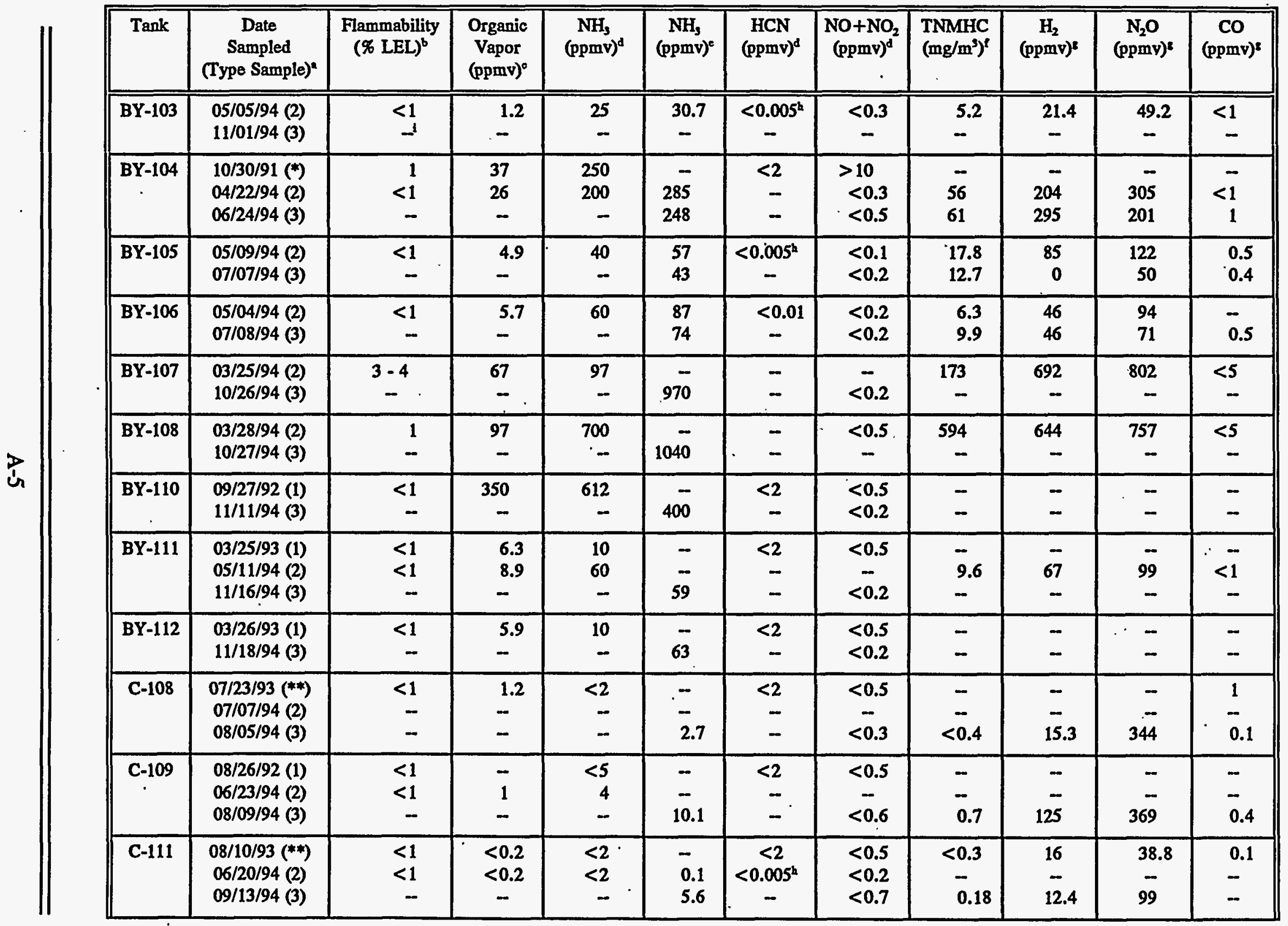


Table A-2. Ferrocyanide Tank Vapor Sampling Summary (Continued)

\begin{tabular}{|c|c|c|c|c|c|c|c|c|c|c|c|}
\hline Tank & $\begin{array}{c}\text { Date } \\
\text { Sampled } \\
\text { (Type Sample) }\end{array}$ & $\begin{array}{l}\text { Flammability } \\
\text { (\% LEL) }^{\mathrm{b}}\end{array}$ & $\begin{array}{l}\text { Organic } \\
\text { Vapor } \\
\text { (ppmv) }\end{array}$ & $\begin{array}{c}\mathrm{NH}_{3} \\
(\text { ppmv) }\end{array}$ & $\begin{array}{c}\mathrm{NH}_{3} \\
(\text { ppmv) }\end{array}$ & $\begin{array}{c}\text { HCN } \\
\text { (ppmv) }^{d}\end{array}$ & $\begin{array}{c}\mathrm{NO}+\mathrm{NO}_{2} \\
(p p m v)^{d}\end{array}$ & $\begin{array}{l}\text { TNMHC } \\
\left(\mathrm{mg} / \mathrm{m}^{3}\right)^{f}\end{array}$ & $\underset{\text { (ppmv) }}{\mathrm{H}_{2}}$ & $\begin{array}{c}\mathrm{N}_{2} \mathrm{O} \\
(\mathrm{ppmv})^{\mathrm{R}}\end{array}$ & $\begin{array}{c}\mathrm{CO} \\
(\mathrm{ppmv})^{\mathrm{s}}\end{array}$ \\
\hline C-112 & $\begin{array}{l}03 / 18 / 92(1) \\
06 / 24 / 94(2) \\
08 / 11 / 94(3)\end{array}$ & $\begin{array}{r}<1 \\
<1 \\
-\end{array}$ & $\begin{array}{c}<0.2 \\
<0.2 \\
-\end{array}$ & $\begin{array}{r}<5 \\
4 \\
-\end{array}$ & $\begin{array}{l}- \\
- \\
22.8\end{array}$ & $\begin{array}{r}<2 \\
- \\
-\end{array}$ & $\begin{array}{c}<2 \\
- \\
<0.7\end{array}$ & $\overline{-}$ & $\frac{-}{204}$ & $\begin{array}{r}- \\
550\end{array}$ & $\overline{-}$ \\
\hline$T-107$ & $10 / 22 / 92(1)$ & $<1$ & 24 & 203 & - & $<2$ & $<0.5$ & - & - & - & - \\
\hline TX-118 & $\begin{array}{l}07 / 28 / 93 \text { (**) }^{* *} \\
09 / 07 / 94 \text { (2) } \\
12 / 16 / 94 \text { (3) }\end{array}$ & $\begin{array}{r}<1 \\
<1 \\
-\end{array}$ & $\begin{array}{l}0.3 \\
7.8 \\
-\end{array}$ & $\begin{array}{r}10 \\
28 \\
--\end{array}$ & $\overline{38}$ & $\begin{array}{l}<2 \\
- \\
-\end{array}$ & $\begin{array}{c}<0.5 \\
<0.7 \\
-\end{array}$ & $\begin{array}{l}- \\
9.3 \\
-\end{array}$ & $\begin{array}{r}- \\
-\end{array}$ & $\begin{array}{l}- \\
17.2 \\
-\end{array}$ & $\begin{array}{l}-- \\
2.5 \\
-\end{array}$ \\
\hline TY-101 & $08 / 04 / 94$ (2) & $<1$ & 4 & 12 & 16 & - & $<0.2$ & - & - & - & - \\
\hline TY-103 & $08 / 04 / 94(2)$ & $<1$ & 5 & 30 & 31 & -.. & $<0.1$ & - & - & - & - \\
\hline TY-104 & $08 / 05 / 94$ (2) & $<1$ & 2.5 & 24 & 50 & - & $<0.2$ & - & - & - & - \\
\hline
\end{tabular}

- Sample Type:

* Vapor samples taken downstream of tank primary HEPA filter utilizing vapor sampling cart.

** Vapor samples taken from in-tank, non-heated tubes utilizing vapor sampling cart (SUMMA ${ }^{\mathrm{TM}}$ only - no $\mathrm{NH}_{3}$ ).

1 Monitoring performed by Industrial Hygiene technicians using three varying length, non-heated sampling tubes into the tank headspace to evaluate for flammability and toxic vapors.

2 Sampling is performed by lowering gas and vapor collection devices into the tank headspace; requires a handcart of equipment.

3 Sampling involves the mobile vapor sampling laboratory, heated transfer lines, and installation of a water-heated sampling probe into the tank.

b Measured using a combustible gas meter; LEL = Lower Explosive Limit.

c Measured using a Organic Vapor Monitor (OVM). OVM readings are affected by ammonia; OVM ammonia response is about $13: 1$, so that 13 ppmv of ammonia is indicated as 1 ppmv of organic vapors (ppmv = parts per million by volume).

${ }^{d}$ Measured using colorimetric (Dräger ${ }^{\mathrm{TM}}$ ) tubes (values are estimated, and not quantitative).

- Analyses of ammonia sorbent trap samples.

'Total non-methane hydrocarbon (TNMHC) concentrations measured for SUMMA ${ }^{\mathrm{TM}}$ canister samples.

- Analyses of SUMMA ${ }^{\mathrm{TM}}$ canister samples.

${ }^{\text {h }} \mathrm{HCN}$ determinations obtained by special sorbent trap; values are below detection limit of measurement technique.

i -- Data not yet available or not obtained by this technique. 


\section{DISTRIBUTION}

Number of copies

OFFSITE

7

U.S. Department of Energy

Trevion II

12800 Middlebrook Road

Germantown, MD 20874

James V. Antizzo, EM-36

Charles O'Dell (5), EM-36

Shirley Campbell-Grizzel, EH-15

1

U.S. Department of Energy

656 Quince Diamond Road

Room 235, EM-20.1

Gaithersburg, MD 20879

Cynthia Hilland

1

U.S. Department of Energy

Savannah River Operations Office

P.O. Box A

Aiken, SC 29808

Thomas C. Temple

1.

Charles S. Abrams

1987 Virginia

Idaho Falls, ID 83404

1

David O. Campbell

102 Windham Road

Oak Ridge, TN 37830

1 . Fred N. Carlson

6965 North 5th West

Idaho Falls, ID 83401

1 Billy C. Hudson

202 Northridge Court

Lindsborg, KA 67456 


\section{DISTRIBUTION (continued)}

Number of copies

\section{OFFSITE}

1

William R. Prindle

1556 Crestline Drive

Santa Barbara, CA 93105

1

Alfred Schneider

5005 Hidden Branches Drive

Dunwoody, GA 30338

1

Air Products \& Chemicals, Inc. 7201 Hamilton Blvd

Allentown, PA 18195-1501

George E. Schmauch

1

Battelle Columbus Laboratories

505 King Avenue

Columbus, OH 43201-2693

James A. Gieseke

1

Brookhaven National Laboratory

Upton, NY 11973

Kamal K. Bandyopadhyay

1

Design Science, Inc.

163 Witherow Road

Sewickley, PA 15143

Gary Powers

$1 \quad$ Fauske and Associates, Inc.

16W070 W. 83rd St.

Burr Ridge, IL 60521

Hans K. Fauske 


\section{DISTRIBUTION (continued)}

Number of copies

\section{QFFSITE}

1

Florida State University

Department of Chemistry B-164

Tallahassee, FL 32306

Greg R. Choppin

2

G \& P Consulting, Inc. 3640 Ballard Road

Dallas, OR 97338

J. Michael Grigsby

Arlin K. Postma

1

Harvard University

295 Upland Avenue

Newton Highlands, MA 02161

Melvin W. First

1

Hazards Research Corporation

200 Valley Road, Suite 301

Mt. Arlington, NJ 07856

Chester Grelecki

3

Los Alamos National Laboratory

P.O. Box 1663

Los Alamos, NM 87545.

Steve F. Agnew

Steve W. Eisenhawer

Thomas E. Larson

1

MTT/Department of Nuclear Engineering

77 Massachusetts Ave.

Room 24-102

Cambridge, MA 02139.

Mujid S. Kazimi 


\section{DISTRIBUTION (continued)}

Number of copies

OFFSITE

Nuclear Consulting Services, Inc.

P.O. Box 29151

Columbus, OH 43229-0151

J. Louis Kovach

Qak Ridge National Laboratory

1

Emory D. Collins

P.O. Box 2008

7930, MS-6385

Oak Ridge, TN 37831-6385

1

Charles W. Forsberg

P.O. Box 2008

MS-6495

Oak Ridge, TN 37831-6495

1

Thomas S. Kress

P.O. Box 2009

9108, MS-8088

Oak Ridge, TN 37831-8088

1

Rice University

5211 Paisley

Houston, TX 77096

Andrew S. Veletsos

2

Sandia National Laboratories

P.O. Box 5800

Albuquerque, NM 87185

Dana A. Powers, MS-0744

Scott E. Slezak, MS-0741 


\section{DISTRIBUTION (continued)}

Number of copies

\section{QFFSITE}

3

Science Applications International Corporation

20300 Century Blvd, Suite 200-B

Germantown, MD 20874

Ray S. Daniels (3)

State of Washington - Department of Ecology

$1 \quad$ Michael T. Gordon

P. O. Box 47600

Olympia, WA $98504-7600$

Alex Stone

1315 W. 4th Avenue

Kennewick, WA 99336

1

University of South Carolina

Department of Electrical and Computer Engineering

Swearingen Engineering Center

Columbia, SC 29208

Joseph S. Byrd

1

University of Washington

Center for Process Analytical Chemistry

Chemistry Department BG-10

Seattle, WA 98195

Bruce R. Kowalski

1

Vanderbilt University

P.O. Box 1596, Station B

Nashville, TN 37235

Frank L. Parker 


\section{DISTRIBUTION (continued)}

Number of copies

\section{OFFSITE}

1

Waste Policy Institute

555 Quince Orchard Road, Suite 600

Gaitherburg, MD 20878-1437

Donald T. Oakley

\section{ONSITE}

11

U.S. Department of Energy. Richland Operations Office

R. F. Christensen (2)

S7-54

R. E. Gerton

S7-54

R. G. Harwood (4)

S7-54

A. G. Krasopoulos

A4-81

Public Reading Room

H2-53

RL Docket File (2)

H5-36

9

Pacific Northwest Laboratory

S. A. Bryan

P7-25

A. R. Felmy

K6-82

B. M. Johnson

$\mathrm{K} 1-78$

M. A. Lilga

P8-38

R. D. Scheele

P7-25

G. F. Schiefelbein

P8-38

C. S. Simmons

K6-77

D. M. Strachan

K9-78

Hanford Technical Library

Westinghouse Hanford Company

H. Babad

S7-30

J. B. Billetdeaux

S7-16

D. C. Board

S1-57

S. R. Moreno

B3-06 


\section{DISTRIBUTION (continued)}

Number of copies

ONSITE

R. J. Cash (5)

S7-15

M. D. Crippen

L5-31

D. R. Dickinson

L5-31

G. T. Dukelow

S7-15

M. E. Huda

R3-08

M. N. Islam

R3-08

D. W. Jeppson

L5-31

N. W. Kirch

R2-11

C. A. Kuhlman

B3-30

J. M. McLaren

H0-34

J. E. Meacham (2)

S7-15

N. J. Milliken .

H4-62

M. A. Payne

S7-14

F. R. Reich

L.5-63

B. C. Simpson

R2-12

H. Toffer

H0-38

W. T. Watson

H0-38

W. D. Winkelman

L5-55

Central Files

L8-04

Document Processing and Distribution (2)

L8-15

EDMC

H6-08

OSTI (2)

L8-07

TFIC

R1-20 
This page intentionally left blank. 